\title{
Hemolymph of molluscan origin: from biochemistry to modern biomaterials science
}

\author{
Tomasz Machałowski ${ }^{1,2}\left(\mathbb{0} \cdot\right.$ Teofil Jesionowski $^{1}$
}

Received: 28 September 2020 / Accepted: 23 November 2020

(c) The Author(s) 2020

\begin{abstract}
Molluscan hemolymph is a unique kind of body fluid, which in many respects is analogous to human blood, although there are several crucial differences. Here, for the first time, we critically analyze the prospects for applications of this fluid in modern biomaterials science. Particular attention is paid to the biochemistry and chemistry of molluscan hemolymph, as well as to hemocytes and hemocyanins as key functional players within this unique biological fluid. We focus on hemocytes as multifunctional hemolytic cells involved in immune response, and especially in the biomineralization process. The next part of the review contains a discussion of molluscan shell formation and regeneration from different points of view. Finally, we consider the challenges, solutions, and future directions in the application of molluscan hemolymph for bioinspired material chemistry and biomedicine.
\end{abstract}

Keywords Hemolymph $\cdot$ Hemocytes $\cdot$ Biomimetic $\cdot$ Scaffolds $\cdot$ Biomaterials $\cdot$ Biomineralization

\section{Introduction}

The phylum Mollusca, with around 200,000 living species [1], represents a huge, morphologically, and ecologically diverse group of invertebrate animals. This phylum is the second largest after Arthropoda [2]. Scientific interest in these animals is also very diverse, and includes such topics as the use of selective classes (Gastropoda and Bivalvia) as natural environmental biomarkers [3-8], and as large-scale sources of feed and food [1, 9-12] obtained from helicicultures [13-18] and aquacultures [19]. Industrially cultivated, or harvested, mollusks are a well-known source of huge amounts of shell-based waste materials worldwide. One of the novel directions in the utilization of molluscan shells is based on their demineralization [20] and the isolation

Tomasz Machałowski

tomasz.g.machalowski@doctorate.put.poznan.pl

Teofil Jesionowski

teofil.jesionowski@put.poznan.pl

1 Faculty of Chemical Technology, Institute of Chemical Technology and Engineering, Poznan University of Technology, Berdychowo 4, 60965 Poznan, Poland

2 Institute of Electronics and Sensor Materials, TU Bergakademie Freiberg, Gustav-Zeuner Str. 3, 09599 Freiberg, Germany of organic matrices known as conchixes [21]. Some other products of molluscan origin, for example, molluscan slime (mucus), have found applications in the pharmaceutical, bioengineering and cosmetic industries [16, 22-24]. Undervalued over the years, molluscan hemolymph is also now recognized as a potential source of biomacromolecules (peptides) with antimicrobial, antiviral, antifungal, and anticancer activity. Such terrestrial gastropod species as Achatina fulica (Bowdich, 1822), Cornu aspersum (ex. Helix aspersa) (Müller, 1774) and the aquatic mollusk species as Rapana venosa (Valenciennes, 1846), Megathura crenulata (Sowerby, 1825) are only a few selected examples from which hemolymph is used as a source of such biologically active substances [25-33].

Hemocytes, as multifunctional cellular components of molluscan hemolymph, are also a focus of research [34, 35]. They are responsible for many aspects of molluscan life, including immune response, biomineralization, shell formation, and regeneration processes [9, 36-38]. There are several examples of applications of both mulluscan hemolymph and hemocytes in biomaterials science and biomimetics. Thus, biomimetic deposition of nanocrystalline calcium carbonate on the surfaces of such external templates as biocompatible metal alloys [39] or natural 3D scaffolds, such as chitinous or collagenous matrices $[34,40]$ has been the subject of recent reports. It has been suggested [34] that 
in vivo and ex vivo cellular biomineralization of external templates by deposition of biological $\mathrm{CaCO}_{3}$ might find real applications in tissue engineering in the near future.

The main goal of this review is to analyze and critically discuss for the first-time molluscan hemolymph and its components as potential renewable sources for application in biomedicine, biomaterials science, and biomimetics.

\section{Molluscan hemolymph and hemocytes: diversity, composition, and functions}

\subsection{Functions and biochemical composition of hemolymph}

Hemolymph (or haemolymph) is the body fluid analogous to blood found in such organisms as mollusks, arthropods, and insects [41-50]. This complex mixture contains diverse biochemically and pharmacologically active components $[25,51,52]$.

The earliest study of the composition and functions of molluscan hemolymph was conducted in the mid-nineteenth century by Leydig, who described observations of the plasma of the river snail Paludina viviparus (Montfort, 1810) [53]. We owe to him the first description of hemocytes, as "nucleated corpuscles that sometimes extend pseudopodia and collect into masses", cited in [54]. Subsequently, other important observations were reported by Fredericq [55], who discovered molluscan hemocyanin, and Cuénot, who gave a characterization of hemolymph and hemocytes [56, 57]. Nevertheless, molluscan hemolymph remains a current field of study [25, 58-67]. The main function of this fluid, which exists in an open circulatory system, is the transport of oxygen, metabolites, and other components essential for the life of mollusks. It is composed mainly of water, but also of inorganic salts and organic compounds, mostly carbohydrates, proteins, lipids, enzymes, respiratory agents (hemocyanin), and free suspended cells called hemocytes [17, 30, 68-77] (see Fig. 1). As reported by Rousseau et al., molluscan hemolymph is one of the three main calcium source components, together with gill and mantle, involved in the biomineralization process [78].

Ziętek et al. [71] established normal ranges of selected biochemical parameters of the hemolymph of the land snails C. aspersum maxima and Cepaea nemoralis (Linnaeus, 1758). For the first species, the authors obtained the following norms: aspartate aminotransferase (AST) activity 26-38 $\mu / 1$, alanine aminotransferase (ALT) activity $0-11 \mu / 1$, amylase activity 9-16 $\mu / 1$, urea concentration 3-6 mg/dl, triglyceride concentration $16-20 \mathrm{mg} / \mathrm{dl}$. For the second species, the values were the following: AST activity $30-80 \mu / 1$, ALT activity $0-15 \mu / 1$, amylase activity $12-15 \mu / 1$, urea concentration $5-8 \mathrm{mg} / \mathrm{dl}$, triglyceride concentration $18-24 \mathrm{mg} / \mathrm{dl}$. It is reported that after infection by parasites, the activity of such aminotransferases (ALT and AST) dramatically increases [79]. In 1999, Zelck described glycosidase activities in the plasma of native and schistosome-infected freshwater snail Biomphalaria glabrata (Say, 1818). The following glycosidases were detected in the plasma: $\beta$-D-fucosidase, $\beta$-D-glucosidase, $\beta$-D-galactosidase, $\beta$-D-mannosidase, $\beta$-Dglucuronidase, $N$-acetyl- $\beta$-D-galactosaminidase, $N$-acetyl$\beta$-D-glucosaminidase, and lysozyme. The author reported that at the physiological $\mathrm{pH}$ of hemolymph (in the range 7.2-7.4), enzymatic activity was about $10-50 \%$ of the maximum activity at each enzyme's respective optimum acid $\mathrm{pH}$. Based on the results obtained, the author concluded that enzyme activity levels correlate with the progress of infection; for more details see [77].

It has been reported that the concentration of lipids in hemolymph is lower in aquatic mollusks than in terrestrial species. Heras and Pollero observed in 2002 that lipid concentration in freshwater snail Pomacea canaliculata (Lamarck, 1822) plasma ranges between 127 and $210 \mu \mathrm{g} /$ $\mathrm{ml}$, the values in hemocytes ranging from 54 to $68 \mu \mathrm{g} / \mathrm{ml}$;
Fig. 1 Mulluscan hemolymph composition: general overview

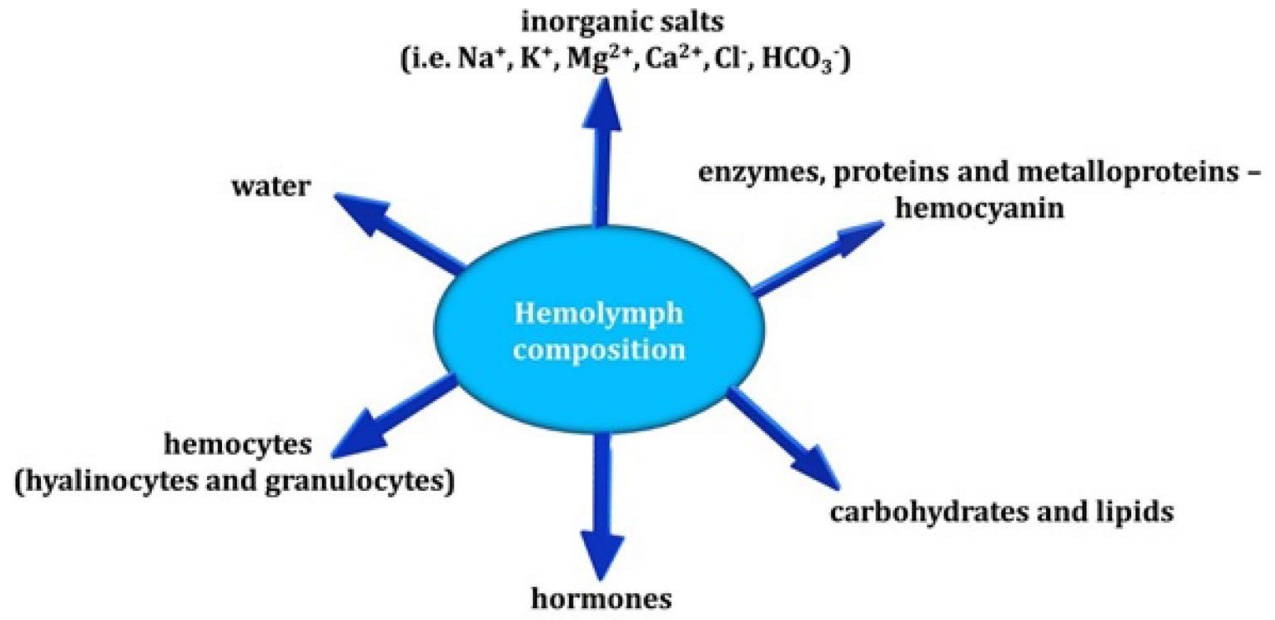


see review [72]. Hoskin, using thin-layer chromatography, determined lipid content in the hemolymph of the hard clam Mercenaria mercenaria (Linnaeus, 1758). The following results were obtained: absolute quantities of cholesterol and triglyceride were $5.2-7.5 \mathrm{mg} / 100 \mathrm{ml}$ and $1 \mathrm{mg} / 100 \mathrm{ml}$, respectively; cholesterol accounted for about $18 \%$ of hemolymph cell sterols and $13 \%$ of serum sterols; and fatty acid content was found to vary over a period of time (4 months); see [80]. An experiment carried out by Lustrino et al. [73] demonstrated that the photoperiod has an influence on triglyceride synthesis in the African snail A. fulica.

Calcium carbonate provides $\mathrm{CO}_{2}$ to enable the formation of a bicarbonate buffer, which is important in the acid-base equilibrium in the hemolymph of snails submitted to stress conditions [81]. As reported by Petrova et al. [82], the dominant buffer system of A. fulica hemolymph plasma is represented by a bicarbonate system associated with hemolymph saturation with carbon dioxide, while the bicarbonate concentration determined in the hemolymph plasma was $33.3 \pm 1.4 \mathrm{mM}$.

In 2005 Santos et al., using the technique of Induction Coupled Plasma Optical Emission Spectroscopy (ICPOES), measured the content of metals in the hemolymph of $B$. glabrata. The authors determined the presence of aluminum, calcium, cadmium, cobalt, chromium, copper, iron, potassium, magnesium, manganese, lead, and zinc [83]. The ion composition of molluscan hemolymph is unique for each individual, and great differences are observed between species; see Table 1.

The volume of hemolymph circulating in mollusks' hemocoel has been reported for many species. In 1916 Leitch [85] reported for the first time the volume of circulating fluid in the freshwater snail Planorbis planorbis (Linnaeus, 1758). The author determined the total weight of hemolymph at $33 \%$ of the tissue weight. Then, in a 1931 study [86], using the Welcker method, the fluid volume of the freshwater snail Planorbis corneus (Linnaeus, 1758) was determined at $55 \%$ of the total tissue weight. In 1950 , using the insulin dilution method, Martin and Hudson [87] reported the hemolymph volume of the sea slug Aplysia californica (Cooper, 1863) at $83.3 \%$ of total animal weight. This very high value may be explained by the anatomy of this marine gastropod, which has very extensive hemocoel. The authors noted that "more than half the body weight in blood can be drained in a few minutes from a single incision into the animal." In 1957 [64], the hemolymph volume in two Pulmonata gastropods, A. fulica and A. ater, was reported. The mean value for the first species was determined at $40.3 \%$ of wet body weight without shell, and for the second at $36.6 \%$ of wet body weight. The computed cellular water
Table 1 Ion composition of hemolymph in selected bivalves and gastropods, adapted from [84]

\begin{tabular}{lllllll}
\hline Species & Class & $\mathrm{Na}^{+}$ & $\mathrm{K}^{+}$ & $\mathrm{Ca}^{2+}$ & $\mathrm{Cl}^{-}$ & $\mathrm{HCO}_{3}^{-}$ \\
\hline Anodonta cygnea (Linnaeus, 1758) & Bivalvia & 15.6 & 0.5 & 8.4 & 11.7 & 14.6 \\
Anodonta grandis (Say, 1829) & Bivalvia & 19.5 & 0.5 & 5.8 & 16.1 & 11.2 \\
Anodonta woodiana (Lea, 1834) & Bivalvia & 15.8 & 0.5 & - & 13.7 & - \\
Corbicula fluminea (Müller, 1774) & Bivalvia & 26.7 & 1.0 & 5.2 & 24.3 & 2.5 \\
Carunculina texasensis (Lea 1857) & Bivalvia & 15.4 & 0.5 & 4.7 & 11.4 & 11.6 \\
Ligumia subrostrata (Say, 1831) & Bivalvia & 20.6 & 0.6 & 3.6 & 12.5 & 11.5 \\
Margaritifera hembeli (Conrad, 1838) & Bivalvia & 14.6 & 0.3 & 5.2 & 9.3 & 11.9 \\
Margaritifera margaritifera (Linnaeus, 1758) & Bivalvia & 14.4 & 0.5 & 7.8 & 11.4 & - \\
Arion ater (Linnaeus, 1758) & Gastropoda & 62 & 2.7 & 2.3 & - & - \\
Achatina fulica & Gastropoda & 65.6 & 3.3 & 10.7 & 72.2 & 13 \\
Cepaea nemoralis & Gastropoda & 88 & 4.6 & 2.0 & 65.6 & - \\
Eobania vermiculata (Muller, 1774) & Gastropoda & 71 & 3.8 & 5.7 & - & - \\
Eutrochatella tankervillii (Gray, 1824) & Gastropoda & 27 & 1.2 & 3.2 & 24 & 12.5 \\
Helix pomacea (Linnaeus, 1758) & Gastropoda & 59.3 & 4.5 & 10.0 & 49.2 & 40 \\
Incidostoma impressus (Crosse \& Fischer, 1886) & Gastropoda & 30 & 1.2 & 3.7 & 24 & - \\
Lymnaea stagnalis (Linnaeus, 1758) & Gastropoda & 55.3 & 1.7 & 4.4 & 36.2 & 28.3 \\
Lymnaea truncatula (Müller, 1774) & Gastropoda & 49 & 2.4 & 8.3 & 32.1 & 18.4 \\
Pomacea depressa (Nevill, 1885) & Gastropoda & 55.7 & 3.0 & 6.6 & 52.0 & 19.0 \\
Pomacea lineata (Spix, 1827) & Gastropoda & 49.8 & 2.4 & 7.2 & 41.3 & 23.4 \\
Poteria lineata (Chitty, 1857) & Gastropoda & 31 & 1.8 & 5.1 & 25 & 13.7 \\
Sphincterochila candidissima (Draparnaud, 1801) & Gastropoda & 53 & 3.1 & 7.7 & - & - \\
Theodoxusa fluviatilis (Linnaeus, 1758) & Gastropoda & 45.0 & 2.2 & 2.3 & 32.8 & 11.3 \\
Tropidophora cuvierana (Petit de la Saussaye, 1841) & Gastropoda & 89 & 3.5 & 8.0 & 77 & 13.5 \\
Viviparus viviparus (Stein, 1850) & Gastropoda & 34.0 & 1.2 & 5.7 & 31.0 & 11.0 \\
\hline & & & & & &
\end{tabular}


contents were $77 \%$ and $79 \%$, respectively. In the same publication, the author showed excellent agreement between the results for the marine bivalve Mytilus californianus (Conrad, 1837 ) and the freshwater bivalve M. margaritifera. When examples with similar body size and form were compared, the results obtained were, respectively, $50.8 \%$ and $49 \%$ of body weight without shell. These results show that the volume of hemolymph in molluscan hemocoel is related to many factors, such as the size and age of the animal, species, and living habitat. Owing to the huge variation in reported composition and concentrations of metabolites in molluscan hemolymph, we recommend-for better understanding of the biochemistry, composition, and function of this unique body fluid-the following articles $[32,59,60,62,63,76$, 88-93] and one book chapter [84].

Land snails are exposed to annual cycles of activity and dormancy in relation to seasonal changes in environmental parameters, such as temperature or humidity Thus, these organisms must adapt via a range of behavioral and physiological mechanisms to survive under their specific microhabitat conditions [76]. The biochemical parameters and composition of molluscan hemolymph are closely related to many factors, including donor species, physiological condition of the animal, food availability, photoperiod, and state of health. This phenomenon is observed in both the Gastropoda [62, 73, 94-96] and Bivalvia [97] classes. Significant changes in the biochemical profile of mollusks' vital fluids also occur during the dormancy period and hibernation. Moreover, such parameters as seasonally changing food sources are linked to variation in hemolymph metabolites [60]. Thus, before hemolymph can be utilized in biomaterials science, it is necessary to analyze the composition of this natural fluid.

\subsection{Hemocyanin: the main protein of molluscan hemolymph}

The main protein in the hemolymph of mollusks is hemocyanin (Hc), which may constitute up to $90 \%$, and even more, of all proteins in the hemolymph [82]. This glycoprotein is responsible mainly for oxygen transport in various invertebrates and is free floating in the hemolymph volume. This complex respiratory molecule is a type- 3 copper-binding protein, and turns blue upon oxygen binding at the active site [32]. For this reason, oxidized molluscan hemolymph is blue in color. Morphologically, hemocyanins are created by cylindrical multimeric glycoproteins with molecular masses ranging from 3.3 to $13.5 \mathrm{MDa}$. Gastropod hemocyanins (Hcs) are composed of polypeptide subunits (about $400 \mathrm{kDa}$ ), which form decametric complexes measuring between 35 and $38 \mathrm{~nm}$ [98]. Each subunit consists of more than seven paralogous functional units (FUs) [32]. Each FU has a molecular mass of about $50 \mathrm{kDa}$, and contains a di-nuclear $\mathrm{Cu}$ site able to reversibly bind a dioxygen molecule; their isolation is possible after limited proteolysis [99]. Then, such hollow cylindrical decamers form di- or tridecamer structures. It should be highlighted that hemocyanin is the largest polypeptide found in nature, composed of about 400 amino acid residues [26]. Thermal stability tests carried out by a Belgian scientific group [100] showed the exceptional stability of land snail Helix pomatia (Linnaeus, 1758) hemocyanin FUs, with a melting temperature in the range $77-83{ }^{\circ} \mathrm{C}$. Three isomorphs of molluscan hemocyanin were recognized as $\alpha$-hemocyanin $\left(\alpha_{\mathrm{D}}-\mathrm{HlH}, \alpha_{\mathrm{N}}-\mathrm{HlH}\right)$ and $\beta$-hemocyanin ( $\beta$-HlH) [98]. Also, as an important component of the molluscan immune system, hemocyanin displays activity against pathogens [99]. Recently, molluscan hemocyanin has found applications as an antibacterial and antiviral factor owing to its potential phenoloxidase activity. These effects have been demonstrated in a number of reports [30, $31,51,75,101]$. H. pomatia hemocyanin was successfully used as a novel bioadjuvant for viral and bacterial antigens [101]. Furthermore, the effect of Hcs on various cancer cell lines has been studied, because their primary amino acid sequences are very different from mammalian ones. This fact means that this glycoprotein generates potent immunogenicity [102-104]. Moreover, hemocyanins are a very promising class of anticancer therapeutic agents, due to their lack of toxicity or side effects. One example is $\mathrm{H}$. pomatia hemocyanin $(\mathrm{HpH})$, which expresses strong in vivo anticancer and antiproliferative effects in a murine model of colon carcinoma and bladder cancer [104]. Other proteins present in molluscan plasma were detected using electrophoresis by El Dafrawy et al. Their results indicated that the hemolymph of the freshwater snail Biomphalaria alexandrina has major dominant bands corresponding to molecular weights of 20 , 44, 96, 139, and $205 \mathrm{kDa}$ [105].

\subsection{Hemocytes as specialized cells}

Hemocytes (also called amebocytes or haemocytes) constitute the cellular component of hemolymph, but can also be found in connective and vascular tissues [9]. The classification criteria adopted for these specialized cells may be either morphological or functional [106]. Since the 1970s numerous classification criteria, mainly based on the cell morphology and enzyme cytochemistry, have been used to identify circulating hemocyte types [107-110]. Over the years, the terminology used for molluscan cells has changed many times; terms used include amoebocytes, lymphocytes, granulocytes, agranular, and granular leukocytes, macrophages, fibrocytes, monocytelike cells, lymphocyte-like cells, spherical cells (see Table 2). According to more recent studies of morphology, hemocytes can be divided into two main types: granulocytes (granular hemocytes) and hyalinocytes (agranular 
Table 2 Overview of nomenclature used in the literature for molluscan hemocytes

\begin{tabular}{llll}
\hline Species & Class & Reported types of hemocytes & References \\
\hline Biomphalaria glabrata & Gastropoda & Granular hemocytes, hyaline blood cell \\
$\begin{array}{l}\text { Biomphalaria glabrata } \text { and } \\
\text { Biomphalaria straminea }\end{array}$ & Gastropoda & blast-like cells, granulocytes, type I hyalinocytes, type II \\
Crassostrea gigas (Thunberg, 1793) & Gastropoda & hyalinocytes, type III hyalinocytes \\
Crassostrea virginica & Bivalvia & Granulocytes, hyalinocytes and/or agranulocytes \\
Haliotis diversicolor & Bivalvia & Granulocytes, fibrocytes, hyalinocytes \\
Haliotis diversicolor & Gastropoda & Granulocytes, hyalinocytes, blast-like cells \\
Haliotis iris (Gmelin, 1791) & Gastropoda & Monocyte-like cells, lymphocyte-like cells, spherical cells \\
Helix aspersa & Gastropoda & Type I (monocyte-like) and type II (lymphocyte-like) \\
Littorina littorea (Locard, 1886) & Gastropoda & Amoebocytes type A, amoebocytes type B \\
Lymnaea stagnalis & Gastropoda & I, II, and III morphotypes \\
Mytilus californianus & Gastropoda & Amoebocytes \\
Pinctada fucata (Gould, 1850) & Bivalvia & Small basophilic, large basophilic, large acidophilic \\
Pinctada fucata & Bivalvia & Small hyalinocytes, large hyalinocytes, granulocytes \\
Ruditapes decussatus (Linnaeus, 1758) & Bivalvia & Granulocytes, hyalinocytes \\
\hline
\end{tabular}

hemocytes, agranulocytes) [9, 37, 38, 111-113]. The hyalinocytes, which lack granules, have a large nucleus and present poor capacity for phagocytosis. Generally, they are spherical or slightly oval [106]. They usually constitute a less numerous population of hemocytes in the hemolymph volume. Nevertheless, there are some exceptions, such as eastern oyster Crassostrea virginica (Gmelin, 1791), where hyaline cells are the most abundant and dominant in the hemogram [2]. The smallest molluscan hyalinocytes reported in the literature were found in tropical freshwater snail Bulinus africanus (Krauss, 1848), $2.6 \mu \mathrm{m}$ in diameter [114], and the largest in air-breathing freshwater snail Bulinus truncates (Audouin, 1827), $28 \mu \mathrm{m}$ in diameter [115]. In contrast, granulocytes have numbers of cytoplasmic granules and exhibit effective phagocytosing activity $[106,116]$. According to the most scientific reports, this type constitutes the dominant hemocyte population [9]. Granulocytes of different species vary in size from $7 \mu \mathrm{m}$ diameter to $70 \mu \mathrm{m}[114,115,117,118]$. In 1975 [108] it was demonstrated for the first time, based on the Giemsa staining, that the granules present in granulocytes of eastern oyster $C$. virginica may be totally basophilic, totally acidophilic or a composition of both. Hine, in a 1999 review, besides the aforementioned, also described eosinophilic and neutrophilic granules [119]. Research by Bystrova et al. [120] distinguished three types of granules in the granulocytes (GCs) of terrestrial snail Achatina achatina (Linnaeus, 1758). The authors described granules of type I, II, and III, and demonstrated the presence of histamine and serotonin in them. Moreover, they indicated that granulocytes may be considered a functional analog of vertebrate mast cells. Experiments carried out by the Swedish scientist Anne Abolins-Krogis help to understand the crucial function and role of granulocyte content in biomineralization assays [121-124].

There are more recent examples of descriptions of more than two types of hemocyte population (see Table 2) in a single organism. One study [125] proved the presence of five types of hemocytes in B. glabrata. Based on the morphological characterization, the authors recognized blast-like cells, granulocytes, type I hyalinocytes, type II hyalinocytes and type III hyalinocytes. Blast-like cells represented a spherical profile with a central nucleus filling almost the whole cell. Granulocytes were characterized and detected based on the abundance of cytoplasmic granules. Type I hyalinocytes were the most abundant cell type and displayed various cytoplasmic projections. Type II and type III hyalinocytes were reported in this study for the first time. In a recent study [111], using flow cytometry, a small subpopulation of a third type of cells in the footed abalone Haliotis diversicolor (Reeve, 1846) was distinguished from known blastlike cells (see Fig. 2). Hine highlighted that granulocytes at early development stages and at the end of life are agranular. This observation may offer an explanation for the differing descriptions of hemocyte types found in the existing literature.

Over the years, the classification of molluscan hemocytes has been carried out by various methods, for example: light and electron microscopy [38, 117, 126-128], differential centrifugation [129], flow cytometry [111, 112, 116, 130], as well as lectin and antibody binding [88, 131]. Also various kinds of staining, including Giemsa [108, 112, 113, $127,132]$, hematoxylin-eosin [37, 38, 112], calcein AM [36, 37], neutral red [112], Methylene Blue-eosin (Diff-Quick or 
Fig. 2 The representation of three hemocytes subpopulations obtained from $H$. diversicolor. For this purpose, a combination of flow cytometry and light microscopy had been used. $N$ nucleus. Scale bar $10 \mu \mathrm{m}$. Reproduced with permission [111]. Copyright 2019, Elsevier

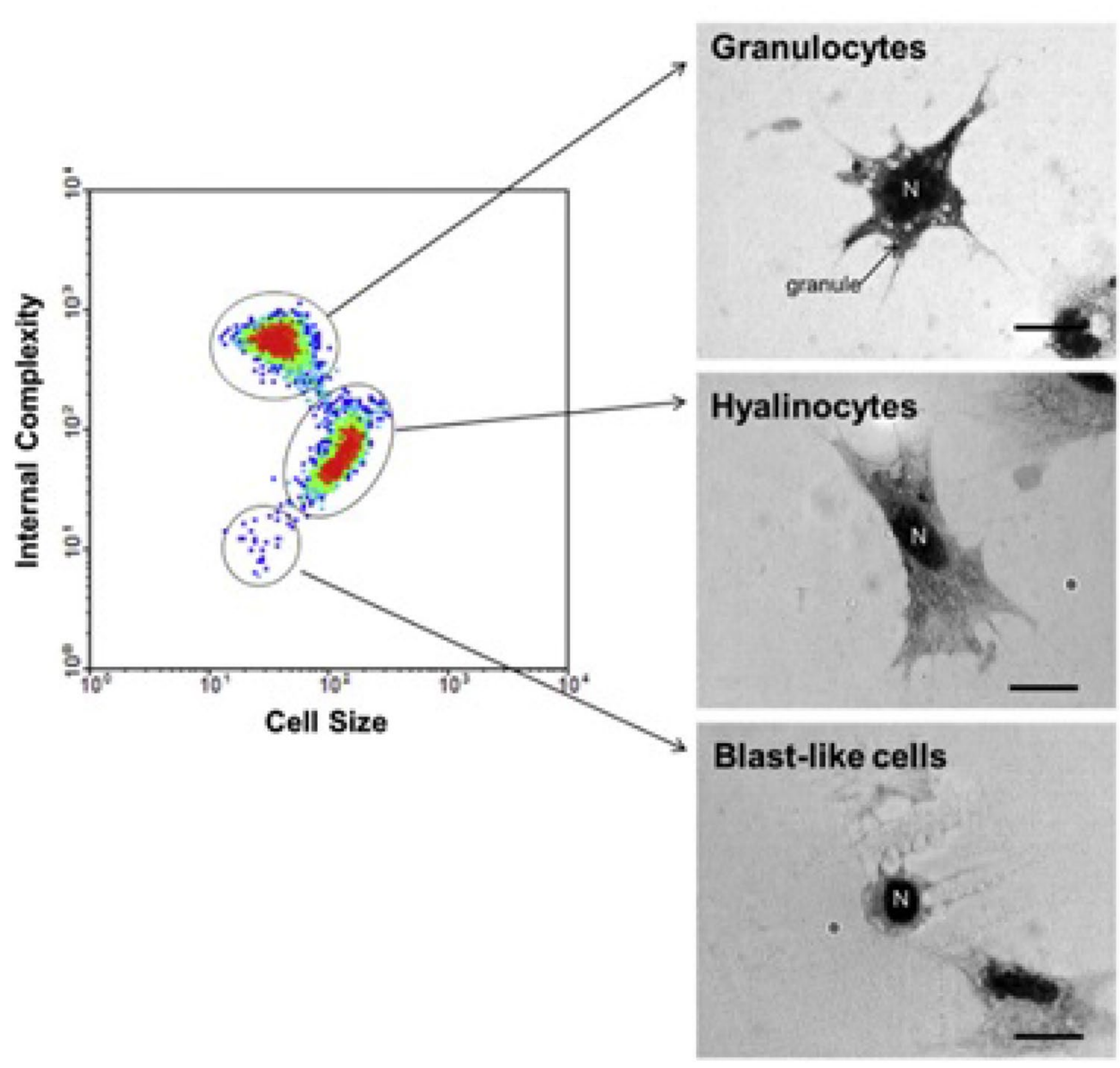

Hemacolor) [113, 133] and acridine orange staining [134], have been used for hemocyte classification and identification. Thus, it is still not clear whether the variety of hemocytes described in the scientific literature represents distinct cell lineages or various functional states and developmental stages, or whether it is dependent on the different techniques used during research [126]. The diversity reflected in the literature may be in part due to some true differences, as well as resulting from varying criteria of differentiation (range of granularity, cell size, ultrastructural features, cell surface/ biochemical markers) and most of all the changing nomenclature adopted by researchers over the years. Today, there is still a lack of biological markers for differentiating specific cell lineages or maturation states [9].

Hemogram is a term referring to blood cell concentration and the number and proportions of hemocyte morphotypes [88]. Adema et al. [117] observed that hemocytes isolated from different gastropod snail species (A. achatina, A. fulica, B. glabrata, B. natalensis, $H$. aspersa, and $L$. stagnalis) presented variation in microscopic morphology, cell size, number of individuals cells per milliliter of hemolymph, as well as peroxidase activity. A feature common to the hemocytes of all of the aforementioned species was the production of superoxide $\mathrm{O}_{2}^{-}$(reactive oxygen intermediates, ROIs) upon
Table 3 Mean number of hemocytes per milliliter of molluscan hemolymph

\begin{tabular}{lll}
\hline Species & $\begin{array}{l}\text { No. of hemocytes/ } \\
\text { ml of hemolymph }\end{array}$ & References \\
\hline Achatina achatina & $4.6 \pm 0.2 \times 10^{5}$ & {$[117]$} \\
Achatina fulica & $1.9 \pm 0.1 \times 10^{5}$ & {$[117]$} \\
Biomphalaria glabrata & $2.5 \pm 0.7 \times 10^{4}$ & {$[117]$} \\
Bulinus natalensis, & $5.7 \pm 0.1 \times 10^{5}$ & {$[117]$} \\
Helix aspersa & $5.0 \pm 2.8 \times 10^{4}$ & {$[117]$} \\
Helix aspersa maxima & $1.3 \pm 0.4 \times 10^{3}$ & {$[106]$} \\
Littorina littorea & $2.3 \pm 1.6 \times 10^{\mathrm{s} 3}$ & {$[88]$} \\
Lymnaea stagnalis & $1.5 \pm 0.1 \times 10^{6}$ & {$[117]$} \\
Mytilus galloprovincialis (Lamarck, & $5.0 \pm 0.5 \times 10^{6}$ & {$[137]$} \\
1819) & & \\
Sunetta scripta (Linnaeus, 1758) & $4.3 \pm 1.1 \times 10^{3}$ & {$[138]$} \\
Villorita cyprinoides (Gray, 1825) & $3.4 \pm 1.2 \times 10^{3}$ & {$[138]$} \\
\hline
\end{tabular}

simulated phagocytosis by zymosan A particles. The number of hemocytes was determined using a Bürker-Türk chamber, the reported value being a mean from four repetitions (see Table 3). The authors highlighted that the mature granulocytes of the land snail selected in this experiment were generally larger and had more elongated shapes in adhering 
to glass than in the case of aquatic species. The average dimensions in length and width for terrestrial snails were, respectively, $44.3 \pm 10 \mu \mathrm{m}$ and $14.5 \pm 0.9 \mu \mathrm{m}$, while corresponding values for aquatic species were $30.9 \pm 8 \mu \mathrm{m}$ and $7.8 \pm 0.5 \mu \mathrm{m}$. In 2003, Polish scientists [106] determined seasonal changes in hemocyte numbers in terrestrial Pulmonata snails of the family Helicidae: $H$. aspersa maxima. The authors distinguished two types of hemocytes in the hemolymph (type I and type II). They further observed that the number was 35\% lower in spring than in autumn, while the hematocrit values were comparable. In 2006, Gorbushin and Iakovleva determined individual variation and seasonal dynamics of hemocytes isolated from the sea snail L. littorea. The authors observed that the number of hemocytes (three morphotypes; see Table 2) change in the course of the year. Hemocyte concentration in the hemolymph ranged from 700 to 4000 cells per $\mathrm{ml}$, reaching a maximum from June to early August. The morphometry of hemocytes from three molluscan species, Trachea vittata (Muller, 1774), $P$. globose, and Indoplanorbis exustus (Dehays, 1833), was described by Mahilini and Rajendran [127].

Huge differences in numbers of circulating hemocytes in the hemolymph are visible when mollusk species are compared [117], and depend on the environmental factors [106]. The results are also influenced by other factors, such as the site of hemolymph sampling: a sample obtained by foot irritation from $B$. glabrata contains about half as many hemocytes as a sample isolated directly from the heart [139]. Other significant factors include animal age, parasite infection, water content in the hemolymph, general condition of the organism, diet, and seasonal state (active or hibernation) $[106,139,140]$. For better understanding of the seasonal variations in molluscan hemocytes, we recommend the following articles [106, 141].

Because of the lack of adaptive immunity, mollusks' immunological processes are based on two factors-physical barriers and the innate immune system-for defense against a broad range of pathogenic agents [28]. The latter system is coordinated by hemocytes [9, 142]. These specialized cells are able to affect pathogens via several immune reactions, including encapsulation [66, 143, 144], phagocytosis $[37,107,111-113,132,145,146]$, nodulation [140], oxidative activity [111, 117, 147-149], and blood coagulation processes [106]. Bayne et al. proposed potential enzyme-mediated mechanisms for the killing of parasite Schistosoma mansoni by B. glabrata hemocytes [148]. Gastropod hemocytes contain a variety of lysosomal enzymes, for example, alkaline phosphatase, nonspecific esterase, and peroxidase [128]. As reported by Dikkeboom, hemocytes from B. glabrata and L. stagnalis are able to produce reactive-oxygen intermediates (ROIs), such as superoxide $\left(\mathrm{O}_{2}{ }^{-}\right)$ and hydrogen peroxide $\left(\mathrm{H}_{2} \mathrm{O}_{2}\right)$ [149]. It should be noted that ROIs, together with the enzyme peroxidase, are involved in the killing of schistosomes by mammalian phagocytes [150]. The aggregation, adhesion, and phagocytosis of molluscan hemocytes have been known for a long time. These phenomena were observed for the first time by Geddes; see [151]. It was observed that mollusks infected by parasites had higher concentrations of circulating hemocytes than those that were not infected (cited in [137]). Hemocytes are also involved in wound healing and shell formation $[36,117,136$, $152,153]$, transporting mineral ions, calcium-rich deposits and calcium-binding proteins [38, 112, 124, 154]. Another study shows their involvement in detoxification, through the accumulation of metallic and organic xenobiotics in their well-developed endolysosomal system [155], as well as their involvement in nerve repair [156]. It is indicated by van der Merwe that hemocytes may be responsible for the production of antimicrobial peptides [19]. In 2016, Hamza-Haffari [157] demonstrated another function of hemocytes which has practical applications: monitoring of the level of toxicity linked to aquatic contaminants, using their phagocytic activity. Recently Hong et al. [111] described other functions of hemocytes: nutrient transportation, metabolite excretion, osmoregulation, and gas exchange. Some of these roles cause a significant reduction in the number of circulating hemocytes, which should then be supplemented by hematopoiesis processes. Therefore, the hematopoietic processes which regulate the proliferation and differentiation of these specialized cells are essential not only for immune reactions, but also for the survival of the animal as a whole [9].

Hemocytes also contain various cellular proteins, which have been identified by such methods as SDS-PAGE and LC-MS/MS [37, 38, 158, 159]. Huang et al. distinguished three categories of peptides based on the proteome analysis; see Table 4. Peptides assigned to the first group (cellular immunity) were found to mediate in such processes as phagocytosis and encapsulation, hemocyte agglutination, migration, endocytosis, and degradation. The humoral immunity category includes peptides involved in the production of reactive-oxygen species (ROS), as well as proteinases and antimicrobial factors. Examples of the third group are proteins related to calcium binding, transport, and metabolism, crucial roles in the biomineralization of mollusks' shells.

There is still debate as to where the hematopoiesis process takes place in mollusks. In the case of gastropods, in the terrestrial species $H$. aspersum it was previously believed that hemocyte proliferation occurred in the mantle epithelium and connective tissue; see review [160]. Research on other, now freshwater species [144] indicated as a possible location the connective tissue of the heart-lung region (pulmonary cavity) in L. stagnalis. Another reported location is the walls of blood sinuses and connective tissue in the region of the kidney in the freshwater snail B. glabrata [106, $161,162]$. Recently, it has been reported that this snail has 
Table 4 Examples of components with partially known functions in the proteome of hemocytes, adapted from [37]

\begin{tabular}{ll}
\hline Description & Function \\
\hline Cellular immunity & \\
Galectin & $\begin{array}{l}\text { Agglutination, pathogen recognition } \\
\text { Inflammation, wound healing } \\
\text { Allograft inflammatory factor-1 } \\
\text { Apoptosis-inducing factor } 3\end{array}$ \\
Humoral immunity & ROS removal, detoxification \\
Copper/zinc superoxide dismutase & ROS generation \\
Dual oxidase 2, partial & Inflammatory response, proliferation \\
Metalloendopeptidase & ROS removal \\
Peroxiredoxin & Blood clotting, protease inhibitor \\
Alpha-2-macroglobulin & \\
Calcification-related & Calcium transport and storage \\
Calreticulin & Calcium binding, actin binding \\
Calponin-3 (fragment) & Calcium binding, actin binding \\
Calponin-2 (fragment) & Calcium metabolism regulator \\
Calmodulin & Calcification, bone resorption \\
Carbonic anhydrase-related protein VIII & Unclear \\
Mantle protein 11 &
\end{tabular}

hematopoietic tissue known as the amoebocyte-producing organ (APO). First described by Jeong et al. [163], this special kind of tissue constitutes a cluster of cells between the pericardium and the posterior mantle epithelia [164]. The hematopoietic cells are contained in the stroma, composed of small fibroblasts and smooth muscle cells surrounded by blood sinuses [2]. As regards other species, it is believed that in many gastropods, hemocyte proliferation occurs in the pericardial sac region, for example the wall of the saccular portion of the renal organ or in histologically and anatomically equivalent structures [9]. It has been reported that the central nervous system of mollusks can modulate hemocyte secretion [61]. The irregularly folded structure (IFS) has been proposed as a hemocyte production/formation site in bivalves [165]. It is not possible at present to specify a single place of hemocyte proliferation for all examples. There are still too few scientific reports concerning hematopoietic sites in many molluscan groups. Moreover, it is possible that more than one primary hematopoietic site exists within each of these groups; see review [9].

\section{The role of hemolymph in biomineralization of molluscan shells}

\subsection{A brief history of the study of biomineralization in Gastropoda and Bivalvia}

The formation of minerals by living organisms is a widespread phenomenon throughout the animal world [166-169]. The term biomineralization means a biological process leading to the creation of a complex composite, such as shell, nacre, enamel or bone [170]. Biominerals take different shapes and sizes, which depend on their function, destination and purpose in nano-, micro-, and macroscale organization, and present enormous diversity [171-173]. Products of biomineralization processes may be observed in six taxonomic groups, and at present more than 60 different types of biominerals are known, such as silicates in diatoms and sponges [174], carbonates in mollusks, corals and other invertebrate phyla [21], and calcium phosphates in vertebrates $[175,176]$. Biominerals are known as inorganic-organic hybrid composites, formed in living organisms as a result of the genetic scheme stored in the code $[177,178]$. Because they combine at least two phases in a specific way, biominerals have unique mechanical and physical properties, and a hierarchical structure that often makes them better for functional use than single-phase materials. They are created by an intriguing interaction at the organic-inorganic interface, through specific surface binding. A crucial role in this process is played by cells (bioreactors) that regulate the rate of crystal formation [179]. Understanding of the biomineralization process may be an inspiration for the design of novel biomimetic materials [180], especially when they are to be fabricated at ambient temperature.

The mineralized shell of mollusks is an essential structure, and often the only one that protects the organism's soft tissue against predators and adverse environmental factors [38]. The unique texture and mechanical properties of the shell has stimulated interest in the biomineralization of Mollusca for millennia. The utilization of nacre as a biomaterial is known from 2000 years ago, when the Mayans used it as a dental implant, as cited in [181]. The first scientific report 
of secretion of a molluscan shell by the mantle was made in 1709 by French physicist and naturalist René Antoine Ferchault de Réaumur, as cited in [160]. In the subsequent years' researchers considered both epithelial cells and subepithelial tissues as responsible for biomineralization. In 1930 De Waele [182] shed a new light on biomineralization theory. That author rejected the function of the mantle cells in genus Anodonta and recognized that shell formation is a truly physicochemical process occurring in the extrapallial fluid (EPF). He further suggested that the necessary substances were brought to the EPF from the hemolymph. De Waele indicated the presence within the extrapallial fluid of a complex of proteins, calcium carbonate and carbon dioxide, which provides ideal conditions for shell formation, through calcium carbonate precipitation at a definite carbon dioxide tension [182]. In the following years, scientists discovered the crucial role of hemocytes in biomineralization [121-124, 136, 154, 160, 183].

Today, analyzing their research, we may conclude that molluscan biomineralization is a complex process in which all of these aspects play a role. In parallel with work on understanding biomineralization mechanisms, the characterization of biominerals was performed. The first experiments of this type were carried out near the beginning of the nineteenth century, and extensive progress was made due to the discovery of optical microscopy, which helped identify various types of structures. One of the earliest reports on this subject comes from 1799, when British chemist Charles Hatchett performed a series of experiments on Haliotidae shell carbonization and dilution using nitric acids. The author identified calcium carbonate as a shell component and observed the organic residue after demineralization. Hatchett did not name this residue, but described it as a "membrane retaining the figure of the shell" [184]. About half a century later, a French researcher, after a process of demineralization of a shell with hydrochloric acid, isolated an organic matrix and called it "conchioline" for the first time [185]. Then in 1930, thanks to further research [186], two polymorphic forms, calcite and aragonite, were distinguished in the shell structure. The author highlighted that the molluscan shell is characterized by a variety of crystal sizes, polymorphs, arrangements, and orientations in different taxonomic groups. It was moreover observed, that in a single shell the major layers present different crystal-grain shapes and arrangements. The next major development in the field took place in the 1960s and 1970s, when new techniques such as transmission electron microscopy (TEM), scanning electron microscopy (SEM), radioisotopes, and biochemical research contributed to the understanding of the ultrastructure of mineralized materials $[175,187]$.

Today, despite the novel and very precise techniques available, many aspects of biomineralization still require further investigation and explanation, because there exist many as yet unexplored phenomena in living organisms. During the last decades several theories concerning mollusk shell formation have been proposed, some of them representing a tremendous departure from accepted views. Previously, the paradigm assumed that control of the mineral superstructure results directly from ion-by-ion additions. Recently, according to "nonclassical" crystallization pathways, researchers have suggested other comprehensive processes, such as aggregation-based crystallization, prenucleation clusters, and amorphous phase mediated crystallization (APMC) [176]. Modern models of molluscan shell formation present the biomineralization process as a complex interaction of hemocytes and extrapallial/mantle cells, with a variety of shell proteins acting as functional domains exhibiting enzymatic activity. At least two enzymes have a crucial role in the biomineralization process: carbonic anhydrase and alkaline phosphatase [78, 188, 189].

Carbonic anhydrase is a metalloenzyme responsible for reverse formation and catalyzes carbonate ion formation from $\mathrm{CO}_{2}$ and $\mathrm{H}_{2} \mathrm{O}$. The active center of the enzyme contains a zinc atom, placed in the pocket formed by the protein part of the enzyme. The zinc atom is coordinated by three imidazole nitrogen atoms of histidine residues (His94, His96 and His119) and a water molecule. The enzyme has been identified in molluscan hemolymph, the cytoplasm of mantle tissue and the plasma membrane fraction [190]. The proposed mechanism of the catalytic process assumes ionization of water to form a $\mathrm{Zn}-\mathrm{OH}^{-}$system, which — being nucleophilic-interacts with a carbon atom of $\mathrm{CO}_{2}$, forming an $\mathrm{HCO}_{3}{ }^{-}$ion. For better understanding of the mechanisms of molluscan shell formation by enzymatically controlled calcification, see the book chapter [190]. In 2005, Rousseau observed that the activity of carbonic anhydrase in gill tissue increased linearly with the age of the animals, but such results were not indicated in relation to the mantle. The circulating level of total calcium increased during the growth of the animals [78]. Although proteins constitute a small percentage of biomineral content, they are directly involved in the control of the synthesis of biocrystals. Even though more than $95 \%$ of bivalve shell is composed of calcium carbonate, and the organic matrix constitutes less than 5\%, this low quantity reinforces the shell 3000 times compared with monolithic $\mathrm{CaCO}_{3}$ [37]. Thereby, the small amount of organic matrix not only reinforces the mechanical properties of the biomineral, but also has a key role in control of the mineralization process, through determination of the size, crystal morphology, specific crystallographic orientation, polymorph or amorphous phase stabilization, and/or crystal growth inhibition [179, 191, 192].

A crucial aspect of the understanding of molluscan biomineralization is the shell damage repair process, which involves re-mineralization of the wound. An excellent explanation of the shell repair process in a land snail 
was described by Seleuddin [193] for H. pomatia. It was observed that in the wound there first appeared a delicate, colorless, organic membrane about $1 \mathrm{~h}$ after injury. Then, after $4 \mathrm{~h}$, the first crystal deposits were visible on the organic membrane surface. The process was observed using a light microscope. In the next hours calcification progressed, and full coverage by a new calcified membrane was observed about $24 \mathrm{~h}$ later. The membrane hardened after 2 days, marking the end of the shell repair process. In 1996 Chen observed that: "wound healing in mollusks differs from that in vertebrates for two reasons. First, no extracellular fibers are formed in mollusks. Second, the hemocyte aggregation in mollusks is reversible and most aggregated cells later disperse, re-entering the circulatory system after wound repair" [135].

\subsection{Possible mechanisms of hemocyte-mediated biomineralization}

\subsubsection{Case Gastropoda}

One of the first reports of evidence of the activity of hemocytes in shell formation and repair in Gastropoda dates from 1951 [136]. Wagge supposed that Helix aspersa (now Cornu aspersum) hemocytes participate in shell damage repair by secretion of the organic matrix, as well as the formation of calcium carbonate crystals [135]. The author observed that hemocyte-rich fluid appears immediately in the damaged area and creates a delicate organic membrane, which then rapidly calcifies to repair the damaged area and protect from parasites. An organic film totally covers the damaged area after $2-3 \mathrm{~h}$. She highlighted that during membrane formation, granulocytes secrete fine protein networks as a mosaic of small polygonal parts. The author mentions that calcification was carried out by both type A and type B amoebocytes by depositing calcium bicarbonate on the protein membrane surface. Newly formed crystals are surrounded by a protein envelope (calcospherite). Wagge [135] proved the presence of radially striated crystals and, based on the chemical and optical tests, characterized them as calcite. In another part of the research, the author observed that the size of the crystal depends on the amount of calcium carbonate available for its formation. Durning, in 1957 [194], questioned this point of view in research related to $H$. aspersa shell repair. He indicated the role of mantle epithelial cells, which filled the wound with a glycoprotein matrix, and noted the absence of a significant number of cells. Moreover, he reported that calcification begins at the outer surface of the matrix and proceeds inward toward the epithelium. A year later, Swedish scientist Anne Abolins-Krogis [123] characterized the calcium carbonate crystallization centers as organic crystals which in the next phase transform into inorganic crystals of calcium carbonate. In 1969, Saleuddin and Wilbur
[195] observed minute crystal formation in the land snail H. pomatia. X-ray diffraction showed that the early-stage crystals are of the aragonite form; the calcite form was also observed, but in later formed layers. The authors propose two explanations: the first based on conversion of aragonite crystals to calcite; and the second, and more probable, on environmental changes during crystal formation which cause a change in the crystals' form. The authors suggest that the structure of the organic matrix components is altered during regeneration. In the study of shell regeneration, it was also found that not all snails formed a new matrix and crystals at the same time. Two newly formed pieces removed from the same animal showed a different rate of shell repair. These results suggest that the formation of new matrix and crystals will depend on several physiological conditions, such as the availability of calcium, the shell proteins, and the site of damage. The shell repair process at the edge of the mantle may be very different from that in the central shell area. The authors did not observe hemocytes at the mineralization front. This may be explained by the method used, as they washed the mantle with tap water to remove shell residue. In a study in the following year, 1970 [196], it was observed that a number of cells (hemocytes) containing calcium spherules were present around the shell regeneration region. The authors dissolved their crystals by means of 10 min' contact with $2 \%$ EDTA and based on XRD analysis obtained a calcite pattern. Research carried out in 1970 by Kapur and Sen Gupta [183] again contradicted the explanation proposed in 1951 by Wagge [135], that the regeneration membrane is formed exclusively by hemocytes, and addressed the alleged mobility of hemocytes in the process of biomineralization. The authors suggested that the membrane appears after precipitation of secreted organic substances present in the extrapallial fluid (EPF). Then, the membrane acts as a scaffold for the hemocytes, which lose their identity, leaving free nuclei and organic matter, and precipitates their calcium-rich granules from cytoplasm, which acts as a crystal nucleation center. These findings are in agreement with those published previously by Abolins-Krogis in her studies on the genus Helix [121, 122]. A histochemical study proved the presence of protein, PAS-positive mucopolysaccharides and acid mucopolysaccharide after hemocyte disorganization. The authors suggest that in this manner the hemocytes improve the calcification matrices in new organic substrates. The disturbance of hemocytes at the site of shell regeneration was compared by the authors to the similar behavior of leucocytes in wound healing in vertebrates.

An ultrastructural study of the shell repair membrane in the snail H. pomatia, performed by Abolins-Krogis, provided a milestone in the understanding of the mechanism of hemocyte-mediated biomineralization in gastropods [154]. The author highlighted that hemocytes present 
within the repair membrane are involved in three different functions: (1) phagocytosis, (2) release of granules, vesicles, and dense bodies and (3) secretion of a fibrillar protein. She observed that about $6 \mathrm{~h}$ after shell damage, the hemocytes created clusters with different degrees of disintegration of individuals. The author described many types of inclusions, including calcium salt, cytoplasmic dense bodies, lipofuscin-type pigment granules, a bleblike protrusion, or a vacuole secreted by disintegrated hemocytes. Cytoplasmic dense bodies took forms with a fibrillar structure or possessed a core-containing inclusion between 0.2 and $0.6 \mu \mathrm{m}$ in diameter. Moreover, besides phagocytosis, the hemocytes enriched the repair membranes with small vesicles and dense bodies, which are involved in the formation of the initial calcifying centra. The author reported that: "some of these cellular constituents were liberated from the degenerated and disintegrated amoebocytes, which were also engaged in the production of the fibrillar protein. Despite the fact that the whole organic mass of the destroyed amoebocytes was added to the repair membrane, the bulk of the substances needed for the complete restoration of the damaged shell apparently come from other sources of the animal body" [154].

Lopez-Lima et al. [191] reported that the nucleation sites consist of an electron-dense material which is responsible for binding calcium. Such materials contain sulfur and acid mucopolysaccharides. Especially the latter are proposed as intermediates in biomineralization, because they sequester many calcium ions and occur in high concentrations at mineralizing foci in distantly related organisms. As an example, the author gave polyanions, which may regulate crystal nucleation and growth. It was also described that dissolved polyanions inhibit the precipitation and growth of calcium minerals by sequestering small nuclei in a soluble phase [191].

In 2007, a group of French researchers [188] determined the effect of calcitonin-related molecules of humanCGRP (calcitonin gene-related peptide) on cellular activity and investigated the control of biomineralization. The authors observed that: "Mollusc shell formation requires calcium $\left(\mathrm{Ca}^{2+}\right)$ and bicarbonate $\left(\mathrm{CO}_{3}^{-}\right)$ions, transported through the mantle via the hemolymph, and the secretion of an organic matrix that interacts with the mineral ions to form either the aragonite or calcite polymorph of calcium carbonate $\left(\mathrm{CaCO}_{3}\right)$. The biomineralization process takes place in the extrapallial space, between inner shell and outer mantle epithelium, and is believed to be under the control of calcium-binding proteins and hormonal factors, such as calcitonin-related molecules (CGRP-like peptides). Epithelial cells from the mantle are responsible from the secretion of matrix molecules whereas hemocytes are involved in ion transportation during shell formation and regeneration" [188].

\subsubsection{Case Bivalvia}

According the classical theory of Bivalvia shell formation [37], a crucial role is played by mantle tissue (precisely, the outer epithelial cells), which can secrete an organic matrix framework and then control calcium carbonate crystal growth at the mineralization front $[37,167]$. All of these processes are accomplished in extrapallial space (EPS), which is the cavity between the shell and the mantle tissue. Both organic and inorganic phases are transported directly via extrapallial fluid (EPF), which provides unique environmental conditions for the self-assembly of shell components. In addition, beside the precursor ions for mineralization, $\mathrm{Ca}^{2+}$ and $\mathrm{HCO}_{3}{ }^{-}$, this fluid contains several other inorganic ions, such as $\mathrm{Na}^{+}, \mathrm{K}^{+}, \mathrm{Mg}^{2+}, \mathrm{Cl}^{-}$, and $\mathrm{SO}_{4}{ }^{2-}$, and ions of minor elements such as strontium and iron. The $\mathrm{pH}$ is usually slightly basic, in the range $7.4-8.3$, for marine and freshwater mollusks [178]. The EPF volume also contains a great number of organic molecules. As the fluid is supersaturated, these macromolecules-in particular Asprich acidic proteins [167] and glycosaminoglycans (GAGs) [178] - are arranged to transiently maintain calcium in solution, by inhibiting the precipitation of $\mathrm{CaCO}_{3}$ as well as by allowing it to precipitate in a timely manner. Marin et al. [178] reported that the protein content of the EPF does not necessarily correlate with the protein content of the mollusk's shell. Moreover, they highlighted that the protein diversity of the EPF appears to be much lower than that of the shell. Falini et al. [197] determined that macromolecules isolated from the aragonitic shell layers of some mollusks induced aragonite formation in vitro. The authors suggest that the substances responsible for these phenomena are $\beta$-chitin, silk fibroin and glycoproteins. An analogous situation was observed in relation to macromolecules from calcite shell layers. The results obtained strongly demonstrate the unique role of the macromolecules in aragonite or calcite polymorph formation. According to this point of view, shell matrix proteins (SMPs) have the greatest impact on crystal selection, orientation, nucleation and growth $[37,168,198$, 199]. Despite immense effort, several controversial issues related to this hypothesis are still the subject of debate: for example, the initiation of crystal nucleation.

In parallel to the widely recognized mantle-mediated calcification theory, a theory of hemocyte-mediated biomineralization was proposed. This hypothesis suggests cooperation between hemocytes and mantle cells. In this case both are involved in the secretion and formation of an organic framework. In addition, hemocytes appear to be capable of bringing about $\mathrm{CaCO}_{3}$ nucleation in vivo as well as transport of the calcium carbonate crystals through the EPF and their release to the shell mineralization front $[36,38,153]$. These free-floating cells seem to fill the space in the large nonexchangeable calcium pool left by 
the mantle tissue, and close the gap in speculation concerning crystal nucleation [37]. It was observed that hemocytes are able to move into the extrapallial space following shell damage [152, 200]. In 1967, Saleuddin observed an increased quantity of hemocytes in injury areas in freshwater mussel A. grandis. The hemocytes were also detected in the subepithelial region of the repairing mantle, suggesting their involvement in the transport of the mineral material [201] and indicating that extrapallial fluid may be a medium for crystal transportation. Nevertheless, the real breakthrough was reported by Professor Mount [36] and his research group. Using calcein AM fluorescent staining and scanning electron microscopy, the researchers observed that hemocytes are present at the mineralization front. They further detected the presence of many cytoplasmic granules and a single crystal inside the molluscan granulocytes (see Fig. 3). Using SEM-EDS analysis they confirmed that cells contain calcium at higher levels than their surrounding regions. Moreover, the group proved that hemocytes can carry calcite crystals to the site of calcification, where they were remodeled and integrated to the growing biomineral of the Eastern oyster $C$. virginica. They found that hemocytes can directly release calcite crystals for subsequent remodeling at the biomineralization site. Based on this analysis, it was demonstrated that hemocytes (in this case granulocytes) may be partially involved in shell crystal formation in the case of oysters.

In 2016, a research group from China [38] observed that hemocytes are involved in the transport of calcium carbonate crystals and their release in the shell regeneration area in the pearl oyster P. fucata (see Fig. 4). These crystal-bearing granulocytes were detected based on SEM-EDS results. The authors observed the direct involvement of granulocytes in the formation of the prismatic layer. The granulocytes were fused into each column and fragmented with the maturation of the shell. The explanation of this phenomenon is unknown, and continued research is required. Moreover, the authors carried out proteome analysis of hemocyte isolated from extrapallial fluid. The results indicated that various biomineralization-related proteins are present, such as NF-kappa B, Mothers Against Decapentaplegic Homolog, cAMP-dependent protein kinase, and G-protein $\alpha$-subunit, as well as calcium binding proteins, e.g. calmodulin, calreticulin, or carbonic anhydrase II fragment. Also, the hemocytes contained shell matrix proteins, such as Mantle Protein 11, Mantle Protein 3, N151 Protein, Shematrin 2, and Amorphous Calcium Carbonate Binding Protein. These data indicate direct cooperation between mantle cells and hemocytes in organic framework creation, and strongly point to the involvement of hemocytes in biomineralization processes.

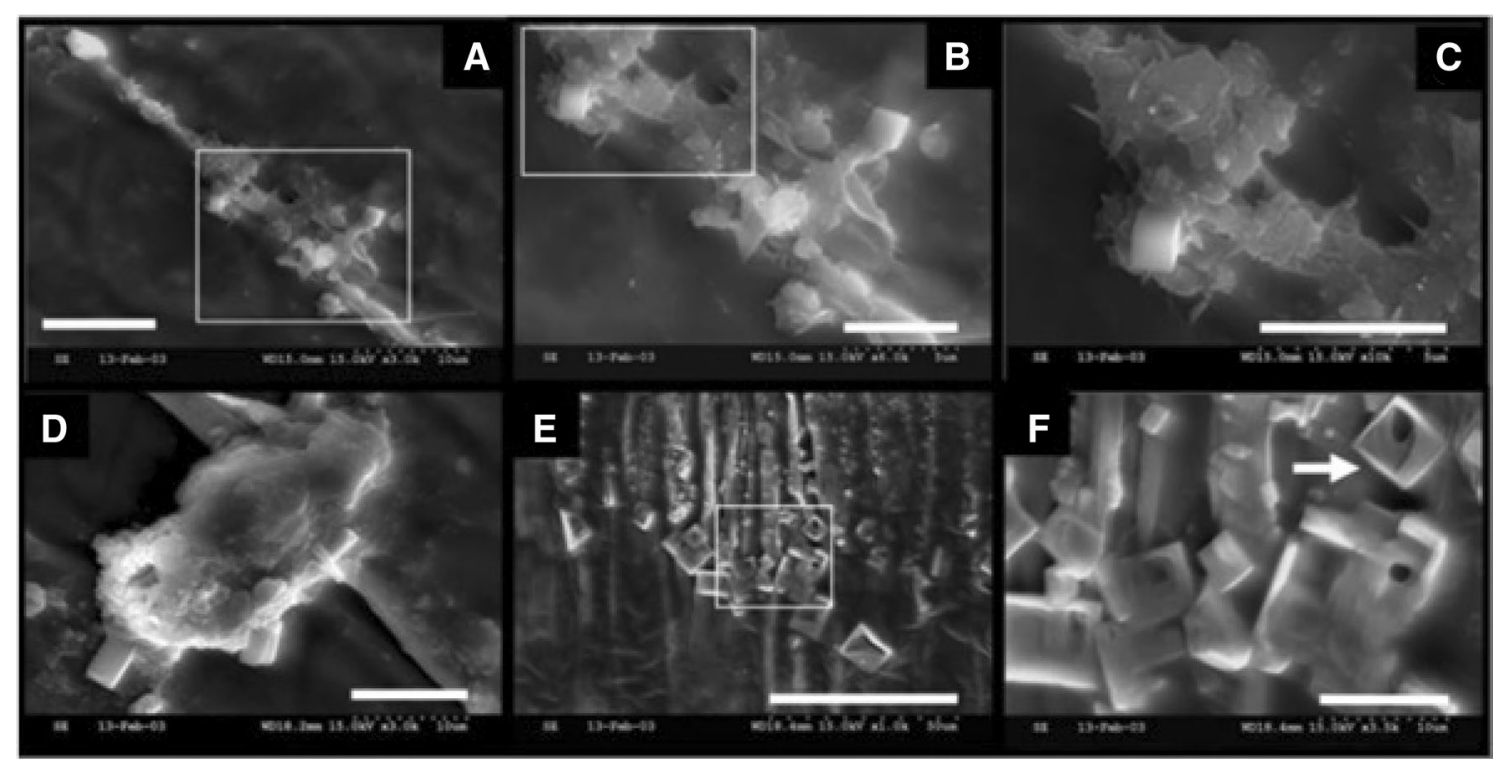

Fig. 3 a The SEM imaginary representation of crystal-bearing hemocytes (granulocytes) of newly formed prismatic shell, $48 \mathrm{~h}$ after injection. The unique cells are orientation along a line of filamentous secretions is visible. Also at least three newly formed crystals are visible. Scale bar $10 \mu \mathrm{m}$. b The higher magnification of the white square in a. The crystals associated with two different granulocytes are visible. Scale bar $5 \mu \mathrm{m}$. $\mathbf{c}$ The higher magnification of the white square in b. A single crystal-bearing hemocyte (granulocyte) is well visible and the crystal size about $2 \mu \mathrm{m}$ by $2 \mu \mathrm{m}$. Scale bar $5 \mu \mathrm{m}$. d Disinte- grated crystal-bearing hemocyte with several crystals at once. Crystals range in size from $1 \mu \mathrm{m}$ by $2 \mu \mathrm{m}$ to $2 \mu \mathrm{m}$ by $4 \mu \mathrm{m}$ edge length. Scale bar $10 \mu \mathrm{m}$. e Crystals that appear to be undergoing remodeling. These crystals occur in the transition between prismatic and foliated shell layers. bar $50 \mu \mathrm{m}$. $\mathbf{f}$ The higher magnification of the white square in $\mathbf{e}$. The walls of the crystals have formed plate-like structures with dimensions more similar to foliated laths (white arrow). Scale bar $10 \mu \mathrm{m}$. Reproduced with permission [36]. Copyright 2004, The American Association for the Advancement of Science 

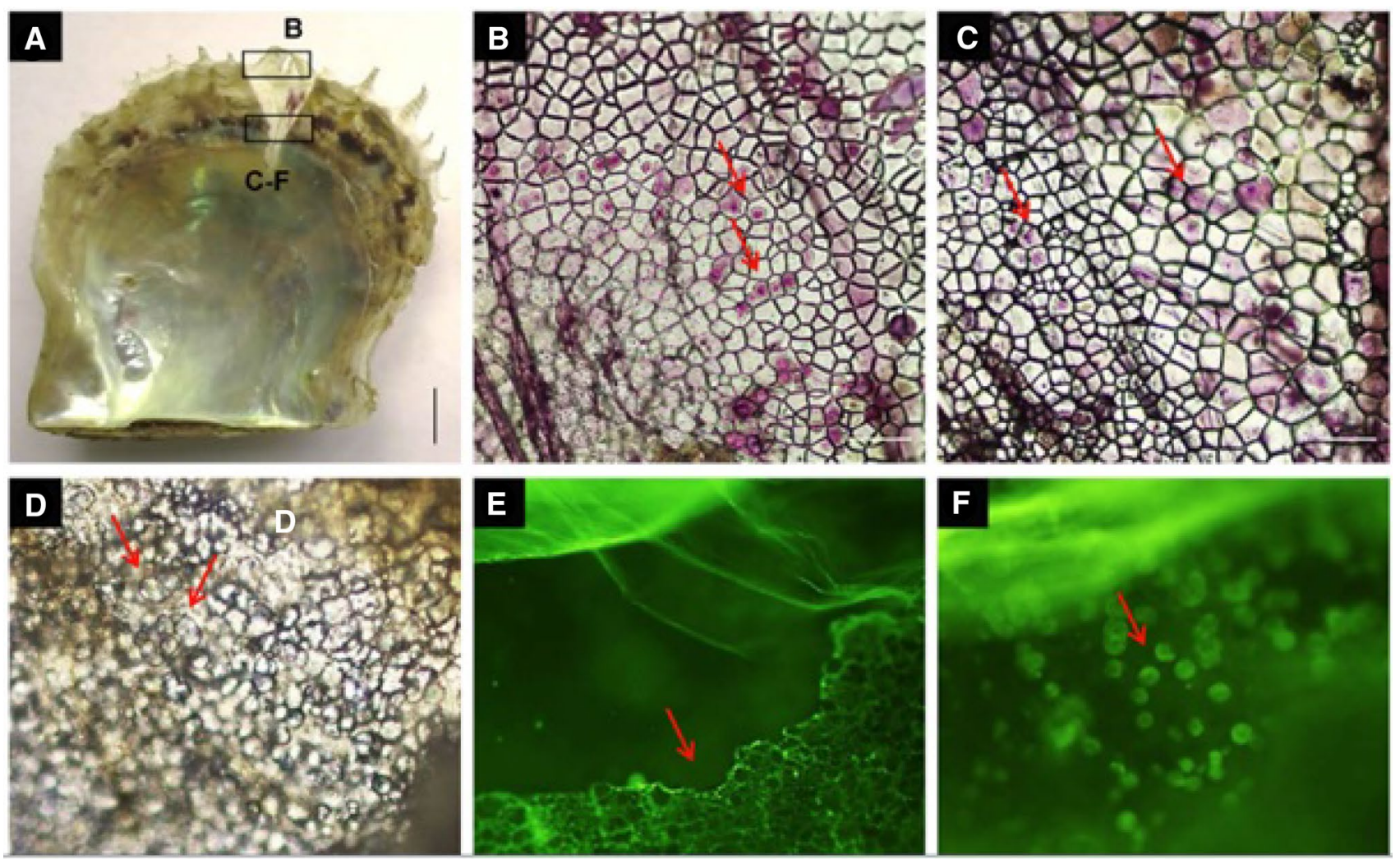

Fig. 4 Light and fluorescent microscopy images indicate at hemocytes presence during shell regeneration of $P$. fucata. a Imaginary representation of the sampling areas for microscopy analyses. The black square indicates the top (b, newborn area) and the bottom (c-f, maturation area) of the regenerated shell. Scale bar $1 \mathrm{~cm}$. b Hematoxylin-eosin (HE) staining of the newly formed area on the regenerated shell. The violet/pink points correspond with stained hemocytes (red arrows). c HE stain of the matured part on the regenerated shell.

Recently, a Chinese group of scientists successfully identified numerous calcium-rich vesicles and crystals in granulocytes of the pearl oyster $P$. fucata using calcein AM staining [37]. Also, the migration speed of granulocytes and hyalinocytes was determined, indicating the strong ability of granulocytes to migrate. Moreover, the authors observed that during shell regeneration, some of the genes involved in calcium metabolism are upregulated. Evidence presented concerning the absence of shell matrix proteins (SMPs) in hemocytes led to the conclusion that they might not be solely responsible for directing the growth of the shell without the involvement of the mantle tissues-in contrast to the findings reported by Li [38].

In summary, attempts to explain biomineralization have been made by many scientists worldwide, and efforts have been made to understand the function of hemocytes. Nevertheless, because of difficulties related to in vivo observations of hemocytes, as well as the limited range of species
The red arrows indicate the stained hemocytes. $\mathbf{d}$ Light micrograph of hemocytes at the mature area of the regenerated shell. The red arrows indicate the hemocytes. e Fluorescent microscopy representation of hemocytes stained by Calcein AM on the regenerated shell. The prismatic layer with no hemocytes distributed on the surface (red arrow). f Fluorescent microscopy representation of hemocytes stained by $\mathrm{Cal}-$ cein AM on the regenerated shell, see red arrows. Reproduced with permission [38]. Copyright 2016, Elsevier

studied, more direct evidence and experiments are needed to enable understanding of this complex mechanism.

\section{Biomimetic design of mineral-based composites using molluscan hemolymph}

Bone tissue engineering is one of the most rapidly developing areas of regenerative medicine. Two decades of research on tissue engineering have already resulted in various types of biomaterials, both synthetic and natural, being proposed for use. However, they are still far from being faultless, and the search for new inventions is actively ongoing [202]. It has been proved that $\mathrm{CaCO}_{3}$-based scaffolds provide improvement in terms of the adhesion, growth and proliferation of osteoblasts and other cells in regenerative medicine [203-205]. It is reported that calcium carbonate (calcite, aragonite, or amorphous-ACC) possesses a 
strong predisposition for biomedical applications, because of its biocompatible [204, 206], biodegradable [205, 207] and osteoinductive properties [203, 208] in tissue engineering. As Woldetstadik reported, cells grown on calcium carbonate scaffolds produce higher levels of transforming growth factor-beta (TGF- $\beta$ ) and vascular endothelial growth factor-A (VEGF-A), which are crucial for the regulation of osteoblast differentiation [209]. A study by Liu et al. [210] indicates that a $\mathrm{CaCO}_{3}$ layer coated on a titanium implant can significantly improve and accelerate the early growth of bone and osseointegration at the early healing phase. This leads to reduced clinical healing times, as well as enhancing implantation outcomes. It is well recognized that in human bone, for example, amorphous calcium carbonate (ACC) is a precursor for crystalline carbonated apatite, and has osteogenic potential [208, 211]. Furthermore, crystalline calcite can serve as a scaffold for human osteoblast transplantation [202]. Finally, calcium carbonates have demonstrated better natural biodegradation properties than calcium phosphates, and have recently been successfully applied as bone regeneration materials [212]. They may prove to be useful in pediatric craniofacial reconstruction, where highly active skeletal remodeling requires rapid resorption of the corresponding scaffold [213-215]. Representatives of the phylum Mollusca are uniquely specialized in the creation of calcium carbonate constructs [153]. Therefore, interest in using mollusks and their hemolymph as a source for bioinspired composite formation has increased over the recent years. The biomimetic creation of calcium carbonate, by imitation of natural processes on external matrices (such as metal or organic scaffolds), may significantly improve the biointegration of such constructs with human cells [216]. On the other hand, the formation of biominerals is an inspiration for the design of unique materials, especially those fabricated under mild conditions.

In 2016 [179], a Chilean scientific group carried out an experiment on the use of chicken outer eggshell membrane for the formation of calcium carbonate crystals by the land snail $H$. aspersa during a shell repair process. The authors thus obtained composite materials based on the calcified matrix. After biomineralization, they determined the type of calcium carbonate $\left(\mathrm{CaCO}_{3}\right)$ polymorph deposited on the external substratum in the injury area. The experiment was carried out as follows. First, after perforation of the shell, a fragment was removed. The operated area was left uncovered as a control or covered with a piece of chicken eggshell membrane (see Fig. 5). The resulting composites and the control were analyzed using SEM, EDS, Raman, and FTIR spectroscopy. The authors observed that in the first hours after injury calcite crystals were present under the eggshell membrane. This polymorph is normally present during chicken eggshell formation. Then an organic matrix, composed mainly of $\beta$-chitin, proteins, and proteoglycans (acid mucopolysaccharides), was deposited by the snail under the crystal layer. The next layers of crystals, formed 24 and $48 \mathrm{~h}$ after injury, presented aragonite polymorphs, characteristic for Helix genus shells. The authors observed that the external matrix had an impact on the crystal polymorph formed at the initial biomineralization stage. In this case the deposited minerals resemble the same crystalline polymorph (calcite) and spherulitic growth that naturally occurred during chicken eggshell formation, which is related to the proteoglycans present under the membrane. Genomic and proteomic approaches confirmed their collagenous composition, enriched by several proteins, including a cysteine-rich ESM protein (CREMP), EDIL3 homologous protein, clusterin, ovocalyxin 32 and 36, and fibrillin. It was established that a keratan sulfate-rich proteoglycan present on the outer side of the eggshell membrane is the site of calcite nucleation. The authors thus confirmed previously published data [217], from a study in which periostracum isolated from four different Mollusca species and eggshell membrane were used in a similar way to investigate mineral deposition in the case of an injury to the land snail Otala lacteal (Mabille, 1883).

Other research conducted by an American group of scientists showed the possibility of calcification of metal disk implants in vivo. The authors used the bivalve mollusk $C$. virginica to identify the secretion of an extracellular matrix (ECM) and cellular activity during shell layer formation by observing folia and prismatic development on different metal alloy surfaces $\left(\mathrm{Ti}_{6} \mathrm{Al}_{4} \mathrm{~V}\right.$ titanium, 7075-T6 aluminum, and $316 \mathrm{~L}$ stainless steel) implanted under the outer mantle edge (OME) [153]. They proposed an explanation for the biomineral formation, stating that: "molluscan shell is
Fig. 5 a The imaginary representation of the shell injection procedure for perforation a small hole into snail shell. b Method of covering perforated hole by external organic matrix. Reproduced with permission [179]. Copyright 2016, Elsevier
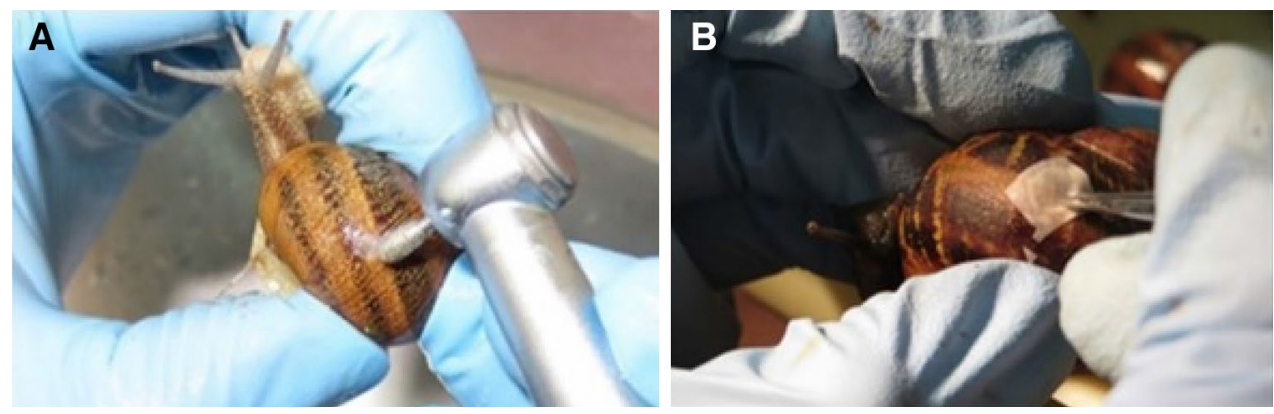

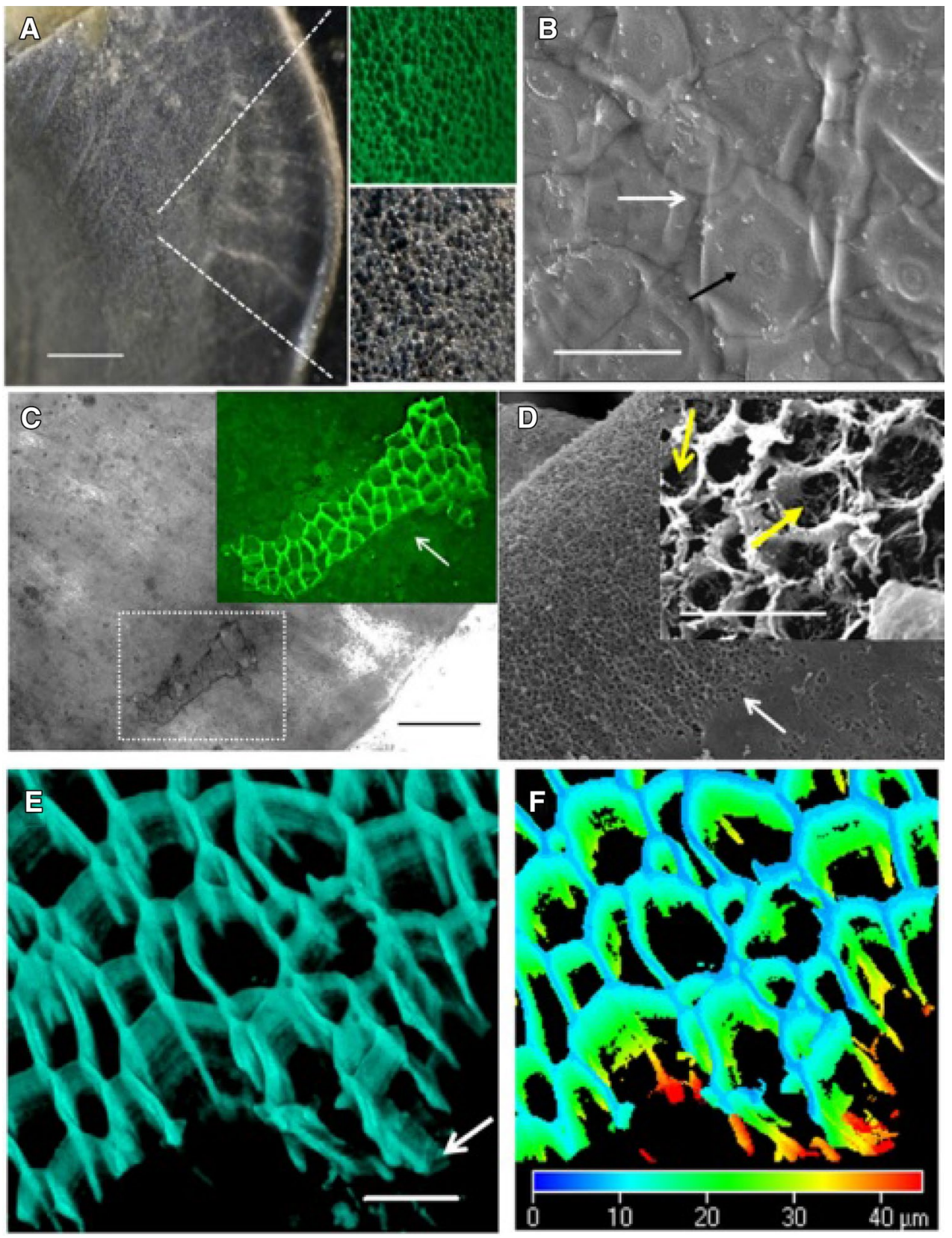

Fig. 6 a, b The newly formed prismatic layer forms on metal implants placed at the shell into notched regions at the shell margin. a The mineralized layer formed on the implant surface. Scale bar $2.5 \mathrm{~mm}$. Upper inset-FITC channel reveals an autofluorescent ECM wall which surrounds the periphery of individual calcite prisms. Lower inset-epi-polarized light channel reveals the forming individual birefringent calcite prisms which comprise the layer. b SEM image of prismatic layer represent the same orientation as in a. The white arrows indicate at ECM membrane surrounding each crystal (thin black line). The black arrow indicates at points to the prism's centrical surface. Scale bar $20 \mu \mathrm{m}$. c Light microscopy image of the outer margin of the OME near the leading edge of the mineralization front. A section of the prismatic layer on the surface of the mantle is visible (boxed). The inset reveals that the walls of the nascent prismatic layer are autofluorescent in the FITC channel. Underly- ing epithelial cells are visible, see white arrow. Scale bar $10 \mu \mathrm{m}$. d SEM images of the outermost fold of the OME, revealing zonation of the mantle epithelia. The epithelium away from the edge of the fold has a relatively flat appearance (lower right corner) as compared to the epithelium near the edge, see white arrow. Scale bar $100 \mu \mathrm{m}$. The insertion shows the ECM walls emanating from the periphery of the epithelia, see yellow arrows. Scale bar $25 \mu \mathrm{m}$. e LSM projection of prismatic shell associated with the surface of the OME. The ECM walls may define the boundaries of individual cells which lie directly beneath the crystalline layer (white arrow). Scale bar $10 \mu \mathrm{m}$. f A depth, c, $\mathbf{d}$ projection of the image in e showing the extent of ECM association with the OME. The prismatic crystalline layer is 15-20 $\mu \mathrm{m}$ thick, however, the ECM appears to extend another $20 \mu \mathrm{m}$ into the OME. Reproduced with permission [153]. Copyright 2015, Elsevier 
Fig. 7 The schematic representation of nonlethal method of isolation of C. aspersum hemolymph. The lower inset show application for ex vivo biomineralization $3 \mathrm{D}$ chitinous scaffolds from poriferan origin. Adapted from [34]

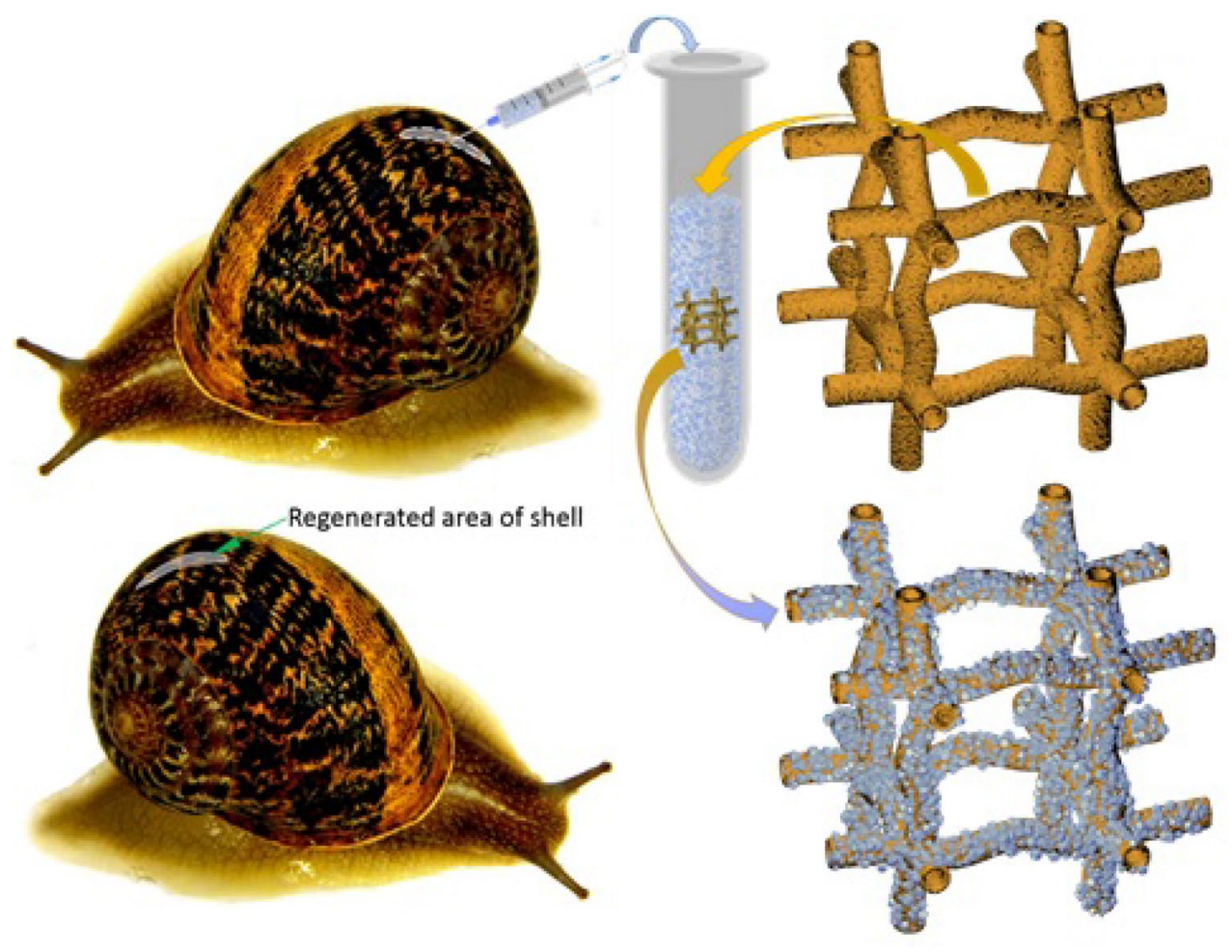

formed through a series of coordinated events involving cells and cell products whereby both organic and mineral phases are secreted, organized, and simultaneously formed." For the implantation of metal disks, a fragment of the posterior margin of the shell was removed. Then metal implants were placed deep enough into the extrapallial cavity to come into contact with the adductor muscle region of the mantle. The researchers collected these after periods of $3 \mathrm{~h}, 24 \mathrm{~h}, 8$ days, 14 days, and 28 days, and then characterized the obtained biocomposites (see Fig. 6).

The same group of scientists also published two joint patents $[39,216]$ related to the deposition of nanocrystalline calcite on matrix surfaces by way of tissue and cellular biomineralization. The authors highlighted that the resulting lightweight durable layer of microcrystalline calcite may improve biocompatibility between inorganic materialsincluding metals such as those used in medical devices - and the body. The researchers have described the in vivo method in detail (analogous to [153]) and have proposed a schematic description of ex vivo biomineralization of matrices by contact with molluscan hemolymph.

Recently, Wysokowski et al. [34] have for the first time developed an effective method for mimicking the shell regeneration process in snails ex vivo. They developed an ex vivo method to perform calcium carbonate deposition using living mollusks' hemolymph and a chitin-based 3D scaffold (see Fig. 7). For this purpose, the marine demosponge Aplysina archeri (Higgin, 1875) [218] and the land snail $C$. aspersum were selected, respectively, as an appropriate 3D chitinous template and as a hemolymph donor. The formation of a calcium-based phase on the surface of chitinous matrix after its immersion in hemolymph was confirmed by specific staining (Alizarin Red S); (see Fig. 8). The authors described the unique role of molluscan hemocytes in the creation of the finetuned microenvironment required for calcification ex vivo. Modern analytical tools, such as X-ray diffraction, Raman spectroscopy and scanning electron microscopy, confirmed the creation of a new biomimetically created composite based on ex vivo synthetized amorphous calcium carbonate (ACC) and calcite. The mineral phase was tightly bound to the surface of a 3D sponge chitin structure. In the near future, the authors plan to determine cytotoxicity and propose biomedical applications for the created mineralized scaffolds.

Biomimetics is now established as a powerful approach for the creation of new composite materials [219] and as a milestone for novel biologically inspired materials chemistry and biomedicine. The field has gained great attention, especially where there is a need for the development of advanced functional materials which feature 3D morphology under mild conditions using biomineralizing invertebrates. A recent report demonstrates that chitinand collagen-based templates can be effectively calcified in vivo by living snails [40] (see Fig. 9). These results indicate that the type of organic template used for in vivo biomineralization has a substantial effect on the nature of the mineral phases, for example, by determining the crystal 

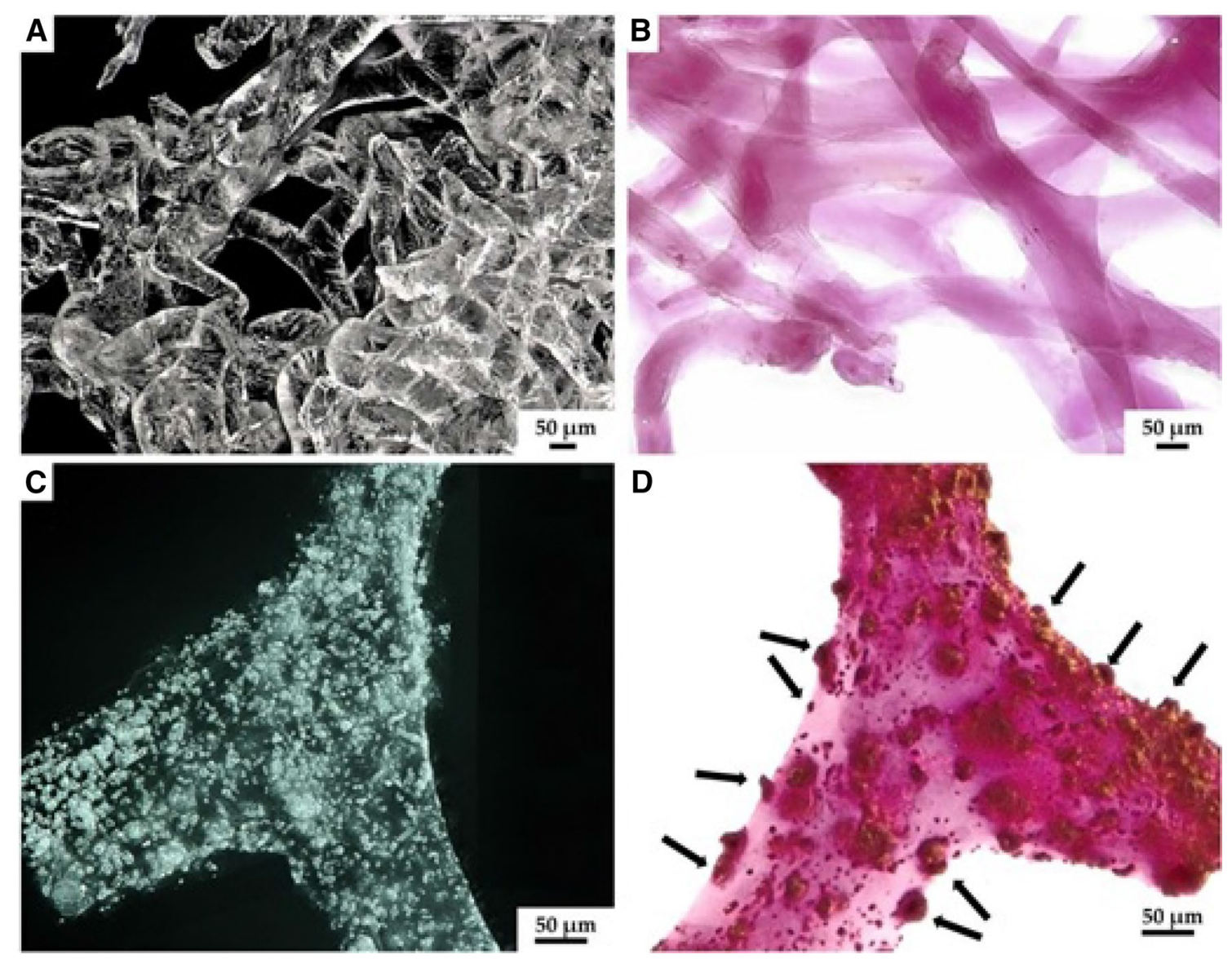

Fig. 8 a The 3D chitinous scaffold isolated from A. archeri prior to ex vivo biomineralization by snail hemolymph became slightly violet-pink b after Alizarin Red S staining. c Well visible calciumbased granular deposits on the chitin surface after biomineralization

polymorph. In the contrast to previous studies of naturally occurring biomineralization, where the aragonite form was observed, chitin and collagen induced calcite formation in the first layer of crystals. The authors of the study plan in the near future to investigate the possible application of the obtained materials in tissue engineering and regenerative medicine.

\section{Conclusion and prospects}

Mollusks have been inspiring people for millennia, and the first use of nacre as a biomaterial is known from 2000 years ago, when the Mayans used it as a dental implant. Nowadays, mollusks are considered a valuable source of meat, cosmetically active products based on snail's mucus as well as biomacromolecules (peptides) with antimicrobial, antiviral, antifungal and anticancer activity. In this review, ex vivo. d Digital light microscopy representation of obtained material after Alizarin Red S staining. Calcium-based deposits possess orange-red color (black arrows). Adapted from [34]

we have attempted to indicate the importance of another mollusks-derived product: hemolymph. This unique body fluid plays a crucial role in biomineralization and in shell creation and regeneration. Recently, the use of molluscs as natural biomineralizers has been reported. Biomimetically conducted biomineralization using live snails and their hemolymph has enabled the design of novel biocomposites based on the diverse organic 3D scaffolds and corresponding calcium carbonate phases. In the near future, the usability of the obtained materials in tissue engineering and regenerative medicine should be investigated. We believe that this review will encourage the scientific community to pay particular attention to molluscan hemolymph-mediated biomineralization as a special biomimetic tool for the creation of novel biomaterials. It is necessary now to develop a nonlethal and fast industrial method for large-scale hemolymph extraction. However, the bioeconomics of molluscan hemolymph-based approaches to biomedicine should be critically studied in the near future. 

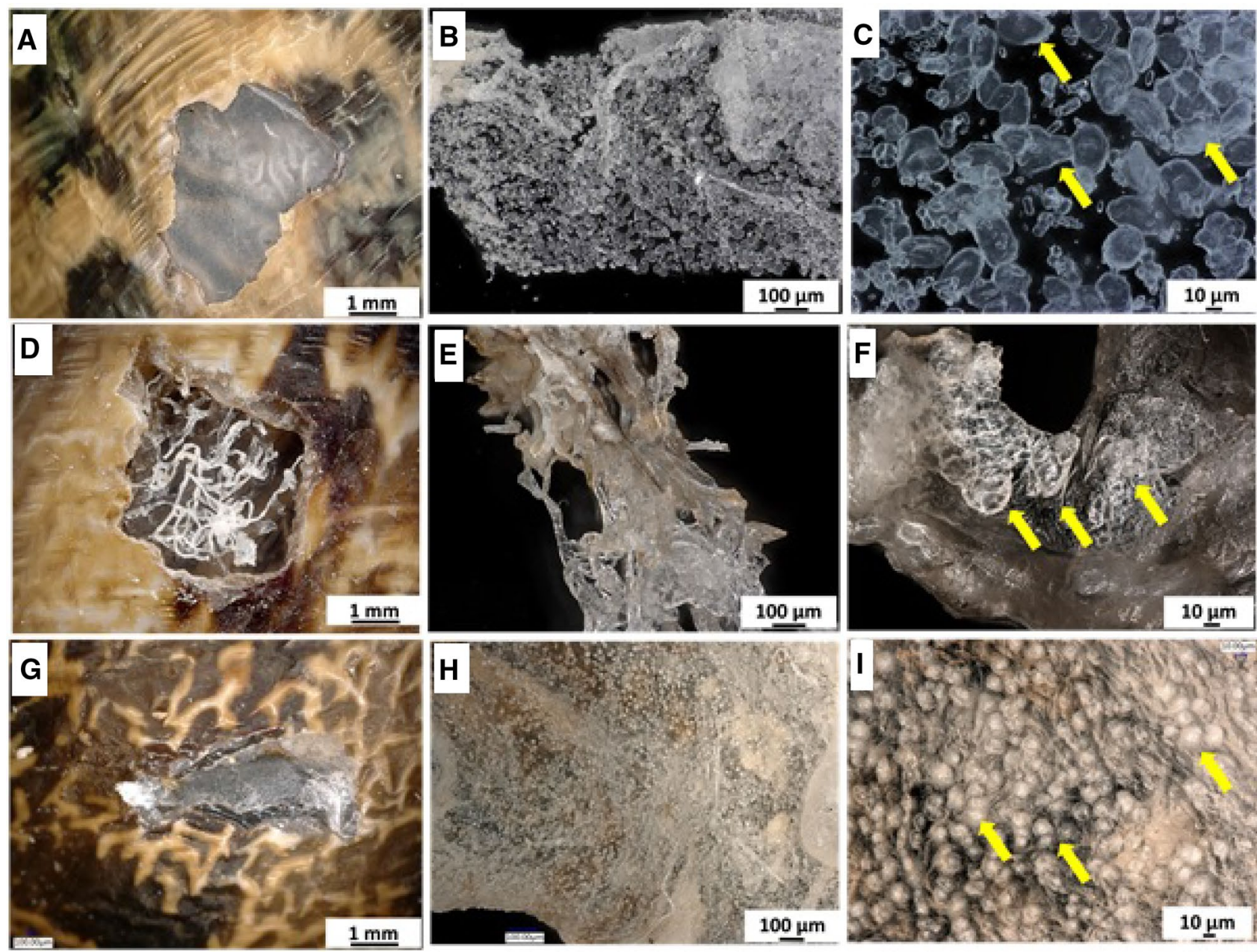

Fig. 9 a The fragment of $C$. aspersum regenerated shell after mechanically hole perforation. Digital microscopy representation of mineralized with calcium carbonate regeneration membrane $\mathbf{b}$, $\mathbf{c}$. d $3 \mathrm{D}$ chitinous scaffold, act like as a template, which fills the hole into damaged shell also $\mathbf{e}, \mathbf{f}$ becomes uniquely mineralized in vivo. $\mathbf{g}-\mathbf{i}$ In the same way, collagen scaffold could be used as a template for in vivo calcification. Calcium carbonate $\left(\mathrm{CaCO}_{3}\right)$ deposits are well visible, see yellow arrows. Adapted from [40]
Funding Open Access funding enabled and organized by Projekt DEAL. Tomasz Machałowski (T.M.) is supported by DAAD (Personal ref. no. 91734605). This research was funded by the Ministry of Science and Higher Education (Poland) (T.M., T.J.).

Availability of data and material Not applicable.

\section{Compliance with ethical standards}

Conflict of interest The authors declare no conflict of interest.

Code availability Not applicable.

Ethics approval Not applicable.

Consent to participate All of the co-workers have agreed to participate.

Consent for publication All of the co-workers have agreed to publication.
Open Access This article is licensed under a Creative Commons Attribution 4.0 International License, which permits use, sharing, adaptation, distribution and reproduction in any medium or format, as long as you give appropriate credit to the original author(s) and the source, provide a link to the Creative Commons licence, and indicate if changes were made. The images or other third party material in this article are included in the article's Creative Commons licence, unless indicated otherwise in a credit line to the material. If material is not included in the article's Creative Commons licence and your intended use is not permitted by statutory regulation or exceeds the permitted use, you will need to obtain permission directly from the copyright holder. To view a copy of this licence, visit http://creativecommons.org/licenses/by/4.0/.

\section{References}

1. J.A.F. Robledo, R. Yadavalli, A. Bassem, E. Pales-Espinosa, M. Gerdol, S. Greco, R.J. Stevick, M. Gómez-Chiarr, Y. Zhang, C.A. 
Heil, A.N. Tracy, D. Bishop-Bailey, M.J. Metzger, Dev. Comp. Immunol. 92, 260-282 (2019)

2. V.J. Smith, A. Accorsi, D. Malagoli, in The Evolution of the Immune System: Conservation and Diversification, edited by M. Davide (Elsevier Inc., 2016), pp. 1-28.

3. D. Kowalczyk-Pecka, E. Kowalczuk-Vasilev, A. Puchalski, B. Kiczorowska, W. Samolińska, R. Stryjecki, K. Czepiel-Mil, Chemosphere 234, 589-595 (2019)

4. D. Kowalczyk-Pecka, S. Pecka, E. Kowalczuk-Vasilev, Environ. Pollut. 222, 138-145 (2017)

5. D. Kowalczyk-Pecka, E. Kowalczuk-Vasilev, A. Puchalski, R. Klebaniuk, Ecotoxicol. Environ. Saf. 148, 713-720 (2018)

6. T.S. Galloway, M.H. Depledge, Ecotoxicology 10, 5-23 (2001)

7. Y. Chen, Y. Si, D. Zhou, F. Dang, Environ. Pollut. 222, 50-57 (2017)

8. P. Williamson, Oecologia 79, 75-79 (1979)

9. E.A. Pila, J.T. Sullivan, X.Z. Wu, J. Fang, S.P. Rudko, M.A. Gordy, P.C. Hanington, Dev. Comp. Immunol. 58, 119-128 (2016)

10. F.S. Ferreira, H. Albuquerque, U.P.D.M. Coutinho, R.R. de Oliveira Almeida, W. da Nobrega Alves, Evid. Based Complement. Altern. Med. 2012, 126938 (2012)

11. Y. Song, C. Cao, R. Qiu, J. Hu, M. Liu, S. Lu, H. Shi, K.M. Raley-Susman, D. He, Environ. Pollut. 250, 447-455 (2019)

12. C.-J. Kao, H.-Y. Chou, Y.-C. Lin, Q. Liu, H.-M.D. Wang, Antioxidants 8, 533 (2019)

13. M. Ligaszewski, P. Pol, Wiadomości Zootech. 1, 53-59 (2018)

14. A. Górka, B. Oklejewicz, M. Duda, J. Nutr. Food Sci. 7, 3 (2017)

15. K. Szkucik, M. Ziomek, W. Paszkiewicz, Ł Drozd, M. Gondek, P. Knysz, J. Vet. Res. 62, 519-526 (2018)

16. M. Ziomek, K. Szkucik, M. Maćkowiak-Dryka, W. Paszkiewicz, Ł Drozd, R. Pyz-Łukasik, Med. Weter. 73, 819-825 (2017)

17. J. Liu, F. Shang, Z. Yang, M. Wu, J. Zhao, Int. J. Biol. Macromol. 98, 786-792 (2017)

18. N. Liao, S. Chen, X. Ye, J. Zhong, X. Ye, X. Yin, J. Tian, D. Liu, J. Agric. Food Chem. 62, 2344-2352 (2014)

19. M. van der Merwe, S. Auzoux-Bordenave, C. Niesler, R. RoodtWilding, Cytotechnology 62, 265-277 (2010)

20. H. Ehrlich, P.G. Koutsoukos, K.D. Demadis, O.S. Pokrovsky, Micron 40, 169-193 (2009)

21. H. Ehrlich, R. Martinović, D. Joksimović, I. Petrenko, S. Schiaparelli, M. Wysokowski, D. Tsurkan, A.L. Stelling, A. Springer, M. Gelinsky, A. Joksimović, Appl. Phys. A 126, 562 (2020)

22. J. von Byern, N. Cyran, W. Klepal, L. Rudoll, J. Suppan, S. Greistorfer, J. Morphol. 279, 187-198 (2017)

23. S. Greistorfer, W. Klepal, N. Cyran, A. Gugumuck, L. Rudoll, J. Suppan, J. von Byern, Zoology 122, 126-138 (2017)

24. S.J. Pitt, M.A. Graham, C.G. Dedi, P.M. Taylor-Harris, A. Gunn, Br. J. Biomed. Sci. 72, 174-181 (2016)

25. P. Dolashka, V. Moshtanska, V. Borisova, A. Dolashki, S. Stevanovic, T. Dimanov, W. Voelter, Peptides 32, 1477-1483 (2011)

26. A. Dolashki, L. Velkova, W. Voelter, P. Dolashka, Z Naturforsch C 74, 113-123 (2019)

27. S.V. Sperstad, T. Haug, H.M. Blencke, O.B. Styrvold, C. Li, K. Stensvåg, Biotechnol. Adv. 29, 519-530 (2011)

28. J. Zhong, W. Wang, X. Yang, X. Yan, R. Liu, Peptides 39, 1-5 (2013)

29. O. Seppälä, J. Jokela, Evolution (NY) 64, 2397-2407 (2010)

30. O. Boyanova, P. Dolashka, D. Toncheva, H.-G. Rammensee, S. Stevanović, Biomed. Rep 1, 235-238 (2013)

31. A. Dolashki, P. Dolashka, A. Stenzl, S. Stevanovic, W.K. Aicher, L. Velkova, R. Velikova, W. Voelter, Biotechnol. Biotechnol. Equip. 33, 20-32 (2019)

32. S. Kato, T. Matsui, C. Gatsogiannis, Y. Tanaka, Biophys. Rev. 10, 191-202 (2018)
33. I. Dharmu, N. Ramamurty, R. Kannan, M. Babu, In Vitro Cell. Dev. Biol. Anim. 43, 306-314 (2007)

34. M. Wysokowski, T. Machałowski, I. Petrenko, C. Schimpf, D. Rafaja, R. Galli, J. Zietek, S. Pantovic, A. Voronkina, V.K.V.N. Ivanenko, B.W. Hoeksema, C. Diaz, Y. Khrunyk, A.L. Stelling, M. Giovine, T. Jesionowski, H. Ehrlich, Mar. Drugs 18, 123 (2020)

35. K. Koiwai, H. Kondo, I. Hirono, Fish. Sci. 85, 521-532 (2019)

36. A.S. Mount, A.P. Wheeler, R.P. Paradkar, D. Snider, Science 304, 297-300 (2004)

37. J. Huang, S. Li, Y. Liu, C. Liu, L. Xie, R. Zhang, Sci. Rep. 8, 4657 (2018)

38. S. Li, Y. Liu, C. Liu, J. Huang, G. Zheng, L. Xie, R. Zhang, Fish Shellfish Immunol. 51, 263-270 (2016)

39. A.S. Mount, N.V. Gohad, D.C. Hansen, K.M. Hansen, M. Beth, M.B. Johnstone, US 9,371,451 B2 (2016).

40. T. Machałowski, M. Wysokowski, I. Petrenko, E. Langer, D. Tsurkan, Appl. Phys. A 126, 469 (2020)

41. J.P. Pandey, R.K. Tiwari, Am. J. Biochem. Mol. Biol. 2, 82-105 (2012)

42. U. Theopold, D. Li, M. Fabbri, C. Scherfer, O. Schmidt, Cell. Mol. Life Sci. 59, 363-372 (2002)

43. J. Tan, M. Xu, K. Zhang, X. Wang, S. Chen, T. Li, Z. Xiang, H. Cui, J. Insect Physiol. 59, 595-603 (2013)

44. R.K. Gupta, S. Langer, P. Manhas, Int. J. Zool. Stud. 2, 252-254 (2017)

45. A.M. Findley, W.B. Stickle, Mar. Biol. 46, 9-15 (1978)

46. M.S. Kerr, Dev. Biol. 20, 1-17 (1969)

47. W.S. Fredrick, S. Ravichandran, Asian Pac. J Trop. Biomed. 2, 496-502 (2012)

48. S. Ravichandran, S. Jeyalakshmi, S. Sudha, R. Anbuchezhian, Bangladesh. J. Pharmacol. 5, 62-67 (2010)

49. R. Kwok, S.S. Tobe, Peptides 27, 590-596 (2006)

50. G. Borsuk, A.A. Ptaszyńska, K. Olszewski, M. Domaciuk, P. Krutmuang, J. Paleolog, PLoS ONE 12, e0170487 (2017)

51. P. Dolashka, A. Dolashki, L. Velkova, S. Stevanovic, L. Molin, P. Traldi et al., Bioactive compounds isolated from garden snails. J Biosci Biotechnol. SE, 147-55 (2015)

52. R. Bayer, US 9,078,906 B2 (2006).

53. F. Leydig, Zeitschrift Für Wissenschaftliche Zool. 2, 125-197 (1850)

54. W.C. George, J.H. Ferguson, J. Morphol. 86, 315-327 (1950)

55. L. Fredericq, Arch. Zool. Expérimentale Générale 7, 535-583 (1878)

56. L. Cuénot, Arch. Zool. Expérimentale Générale 9, 13-90 (1891)

57. L. Cuénot, Arch. Biol. (Liege). 12, 683-740 (1892)

58. S.O. Olagbende-Dada, Afr. J. Pharm. Pharmacol. 9, 295-298 (2015)

59. K. Bislimi, A. Behluli, J. Halili, I. Mazreku, F. Osmani, F. Halili, Int. J. Eng. Appl. Sci. 4, 11-18 (2013)

60. A. Nicolai, J. Filser, R. Lenz, C. Bertrand, M. Charrier, Physiol. Biochem. Zool. 85, 274-284 (2012)

61. S.V. Shabelnikov, O.A. Bystrova, V.A. Ivanov, B.A. Margulis, M. Martynova, J. Exp. Biol. 212, 3211-3220 (2009)

62. D. Suljević, A. Muhić, E. Islamagić, M. Fočak, Acta Biol. Szeged 61, 129-134 (2017)

63. W. Le Clec'h, T.J.C. Anderson, F.D. Chevalier, Parasit. Vectors 9, 32 (2016)

64. A.W. Martin, F.M. Harrison, M.J. Huston, D.M. Stewart, J. Exp. Biol. 35, 260-279 (1957)

65. M. Auguste, A. Lasa, A. Pallavicini, S. Gualdi, L. Vezzulli, L. Canesi, Sci. Total Environ. 670, 129-137 (2019)

66. M.O. Salawu, O.B. Oloyede, A.T. Oladiji, N.O. Muhammad, M.T. Yakubu, Pharm. Biol. 49, 1029-1033 (2011)

67. P. Dolashka, A. Dolashki, W. Voelter, J. Van Beeumen, S. Stevanovic, Int. J. Curr. Microbiol. Appl. Sci. 4, 1061-1071 (2015) 
68. A.A. Dogterom, H. van Loenhout, R.C. van der Schors, Gen. Comp. Endocrinol. 68, 63-68 (1979)

69. A.A. Dogterom, R.C. van der Schors, Gen. Comp. Endocrinol. 339, 334-339 (1980)

70. S.K. Adeboye, A.T. Ogundajo, O.O. Ajayi, O.M. Oluba, J. Pharm. Res. Int. 18, 1-8 (2017)

71. J. Ziętek, L. Guz, S. Winiarczyk, K. Szkucik, M. Ziomek, M. Wysokowski, J. Madany, Ł Adaszek, Pol. J. Vet. Sci. 21, 445-449 (2018)

72. H. Heras, R.J. Pollero, Biocell 26, 111-118 (2002)

73. D. Lustrino, V.M. Tunholi-Alves, V.M. Tunholi, M.P. Marassi, J. Pinheiro, Braz. J. Biol. 70, 129-134 (2010)

74. D. Lustrino, A.C.M. Silva, I.G. Araujo, V.M. Tungoli, V.M. Tunholi-Alves, R.N. Castro, D.P. Carvalho, J. Pinheiro, M.P. Marassi, An. Acad. Bras. Cienc. 89, 2181-2188 (2017)

75. P. Dolashka, A. Dolashki, J. Van Beeumen, M. Floetenmeyer, L. Velkova, S. Stevanovic, W. Voelter, Curr. Pharm. Biotechnol. 17, 263-270 (2016)

76. A. Nicolai, J. Filser, R. Lenz, C. Bertrand, M. Charrier, J. Comp. Physiol. B 181, 457-466 (2011)

77. U.E. Zelck, Parasitology 119, 563-568 (1999)

78. M. Rousseau, E. Plouguerné, G. Wan, R. Wan, E. Lopez, M. Fouchereau-Peron, Comp. Biochem. Physiol. Part A 135, 271278 (2003)

79. V.M. Tunholi, D. Lustrino, V.M. Tunholi-Alves, C.C.C. MelloSilva, A. Maldonado Jr., J. Pinheiro, M.D.L.D.A. Rodrigues, Parasitol. Res. 109, 885-891 (2011)

80. G.P. Hoskin, S.P. Hoskin, Biol. Bull. 152, 373-381 (1977)

81. M.V. Tunholi, D. Lustrino, V.M. Tunholi-Alves, J.G. Silva, C.C.C. Mello-Silva, A. Maldonado, J. Pinheiro, M.D.L.D.A. Rodrigues, Exp. Parasitol. 129, 266-269 (2011)

82. T.A. Petrova, A.Y. Lianguzov, N.M. Malygina, J. Evol. Biochem. Physiol. 52, 37-45 (2016)

83. M.A.V. Santos, E.D.S. Brabo, B.S. Carneiro, K.D.F. Faial, I.R.C. Rodrigues, Rev. Soc. Bras. Med. Trop. 38, 157-160 (2005)

84. L. Deation, in Osmotic Ion. Regul. Cells Anim., edited by D. H. Evans, I (CRC Press, London, 2008), pp. 107-125.

85. I. Leitch, J. Physiol. 50, 370-379 (1916)

86. M.A. Borden, J. Mar. Biol. Assoc. UK 17, 709-738 (1931)

87. A.W. Martin, M.J. Hudson, Anat. Rec. 108, 22 (1950)

88. A.M. Gorbushin, N.V. Iakovleva, J. Biol. Assoc. UK 86, 11751181 (2006)

89. M.L. Ewald, J.W. Feminella, K.K. Lenertz, R.P. Henry, Comp. Biochem. Physiol. Part C 150, 237-245 (2009)

90. F. Halili, K. Bislimi, A.M. Gashi, I.D. Bajraktari, I. Mazreku, N. Aliu, FASEB J. 24, 436 (2010)

91. M.A. Crenshaw, Biol. Bull. 143, 506-512 (1972)

92. W.B. Stickle, T.W. Howey, Mar. Biol. 33, 309-322 (1975)

93. R.F. Burton, Comp. Biochem. Physiol. 57, 135-137 (1977)

94. N.H. Howes, G.P. Wells, J. Exp. Biol. 11, 327-343 (1934)

95. A. Nowakowska, in Hypometabolism: Strategies of Survival in Vertebrates and Invertebrates, edited by A. Nowakowska, M.Ł. Caputa, (Research Signpost, Kerala, 2011), pp. 1-17.

96. L.D. Silva, V.C.S. Amaral, M.C. Vinaud, A.M. Castro, H.H.A. Rezende, D.B. Santos, J.C.B. Bezerra, Braz. J. Biol. 77, 304-311 (2017)

97. C. Ciacci, R. Fabbri, M. Betti, P. Roch, L. Canesi, Invertebr. Surviv. J. 6, 44-48 (2009)

98. G.G. Schäfer, V. Pedrini-Martha, R. Schnegg, R. Dallinger, D.J. Jackson, B. Lieb, Mol. Phylogenet. Evol. 130, 99-103 (2019)

99. N.I. Siddiqui, Y. Yigzaw, G. Préaux, C. Gielens, Biochimie 91, 508-516 (2009)

100. B.T. Yesilyurt, C. Gielens, F. Meersman, FEBS J. 275, 36253632 (2008)
101. V. Gesheva, S. Chausheva, N. Stefanova, N. Mihaylova, L. Doumanova, K. Idakieva, A. Tchorbanov, Int. Immunopharmacol. 26, 162-168 (2015)

102. S. Arancibia, F. Salazar, M.I. Becker, in Bl. Cancer-From Basic Sci. to Robot. Surg., edited by A. Erdem Canda (IntechOpen, 2012), pp. 221-245.

103. M.H. Guncheva, S.J. Todinova, V.P. Uzunova, K.N. Idakieva, Chem. Sel. 4, 11460 (2019)

104. V. Gesheva, S. Chausheva, N. Mihaylova, I. Manoylov, L. Doumanova, K. Idakieva, A. Tchorbanov, BMC Immunol. 15, 34 (2014)

105. S. El-Dafrawy, A.T. El-Din, H.A. Hamid, J. Egypt. Soc. Parasitol. 36, 795 (2006)

106. A. Adamowicz, M. Bolaczek, Zool. Pol. 48, 93-101 (2003)

107. T. Sminia, Z. Zellforsch. 130, 497-526 (1972)

108. T.C. Cheng, Ann. Ann N Y Acad Sci. 226, 343-379 (1975)

109. K. Wolburg-Buehholz, A. Nolte, Z. Zellforseh. 292, 281-291 (1973)

110. C. Stang-Voss, Z. Zellforseh. 156, 142-156 (1970)

111. H.-K. Hong, L. Donaghy, K.S. Choi, Aquaculture 506, 401409 (2019)

112. A.V. Ivanina, H.I. Falfushynska, E. Beniash, H. Piontkivska, I.M. Sokolova, J. Exp. Biol. 220, 3209-3221 (2017)

113. R. Grandiosa, F. Mérien, K. Pillay, A. Alfaro, Fish Shellfish Immunol. 48, 175-184 (2016)

114. C.T. Wolmarans, E. Yssel, J. Ivertabrate Phatol. 56, 1-7 (1990)

115. T.C. Cheng, V.G. Guida, J. Invertabrates Pathol. 35, 158-167 (1980)

116. E.E. Prokhorova, M.K. Serebryakova, A.S. Tokmakova, G.L. Ataev, ISJ Invertabrate Surviv. J. 15, 346-351 (2018)

117. C.M. Adema, R.A. Harris, E.C. van Deutekom-Mulder, J. Invertabrates Pathol. 59, 24-32 (1992)

118. T.P. Yoshino, W.O. Granath, Cell Tissue Res. 232, 553 (1983)

119. P.M. Hine, Fish Shellfish Immunol. 9, 367-385 (1999)

120. O.A. Bystrova, S.V. Shabelnikov, M.G. Martynova, Acta Histochem. 116, 14 (2014)

121. A. Abolins-Krogis, Ark. Zool. 15, 461-474 (1963)

122. A. Abolins-Krogis, Symp. Zool. Soc. Lond. N. 22, 75-92 (1968)

123. A. Abolins-Krogis, Acta Zool. 39, 19-38 (1958)

124. A. Abolins-Krogis, Z. Zellforsch. 142, 205-221 (1973)

125. M.G.S. Cavalcanti, F.C. Filho, A.M.B. Mendonça, G.R. Duarte, C.C.G.S. Barbosa, C.M.M.B. De Castro, L.C. Alves, F.A. Brayner, Micron 43, 285 (2012)

126. G.G. Martin, C.T. Oakes, H.R. Tousignant, H. Crabtree, R. Yamakawa, J. Molluscan Stud. 73, 355-365 (2007)

127. H.M. Mahilini, A. Rajendran, J. Invertebr. Pathol. 97, 20-26 (2008)

128. T. Sminia, L. Barendsen, J. Morphol. 165, 31-39 (1980)

129. T.P. Yoshino, X. Wu, L.A. Gonzalez, C.H. Hokke, Exp. Parasitol. 133, 28 (2013)

130. C. Lopez, M.J. Carballal, C. Azevedo, A. Villalba, J. Invertabrates Pathol. 69, 51 (1997)

131. T.P. Yoshino, W.O. Granath Jr., J. Invertabrates Pathol. 45, 174186 (1985)

132. C.J. Bayne, M.N. Moore, T.H. Carefoot, R.J. Thompson, J. Invertebrate Pathol. 34, 1-20 (1979)

133. L. Donaghy, H.K. Hong, C. Lambert, H.S. Park, W.J. Shim, K.S. Choi, Fish Shellfish Immunol. 28, 87 (2010)

134. S. Izzetoglu, Türk. Entomol. Derg. 36, 163-168 (2012)

135. J.H. Chen, H.Y. Yang, S.W. Peng, Y.J. Chen, K.Y. Tsai, Biol. Bull. NTNU 31, 31-38 (1996)

136. L.E. Wagge, J. Cell Sci. 92, 307-321 (1951)

137. M.J. Carballal, A. Villalba, C. Lopez, J. Invertabrates Pathol. 72, 304-312 (1998) 
138. K. Suresh, A. Mohandas, J. Invertabrates Pathol. 55, 312-318 (1990)

139. S. Noda, S. Loker, Parasitology 98, 35-41 (1989)

140. Z. Gliński, J. Jarosz, in Zjawiska Odporności Przeciwzakaźnej u Bezkręowców (Wydawnictwo UMC, Lublin, 1997), pp. 90-100.

141. M.G. McCormick-Ray, T. Howard, J. Invertabrates Pathol. 58, 219-230 (1991)

142. T.C. Cheng, in Invertebrate Blood Cells, edited by N.A. Ratcliffe, A.F. Rowley (New York Academic, New York, 1981), pp. 233-300.

143. N. Dinguirard, M.G.S. Cavalcanti, X.J. Wu, U. Bickham-Wright, G. Sabat, T.P. Yoshino, Front. Immunol. 9, 2773 (2018)

144. T. Sminia, W.P.W. Van der Knaap, L.A. Van Asselt, Dev. Comp. Immunol. 7, 665 (1983)

145. E. Bachere, D. Hervio, E. Mialhe, Dis. Aquat. Organ. 11, 173$180(1991)$

146. S.E. Fryer, J. Bayne, Dev. Comp. Immunol. 20, $23-37$ (1996)

147. B. Lawal, O.K. Shittu, P.C. Ossai, A.N. Abubakar, A.M. Ibrahim, Br. J. Pharm. Res. 6, 141-154 (2015)

148. C.J. Bayne, U.K. Hahn, R.C. Bender, Parasitology 123, 159-167 (2001)

149. R. Dikkeboom, C.J. Bayne, W.P.W. van der Knaap, J.M.G.H. Tijnagel, Parasitol. Res. 75, 148-154 (1988)

150. J.W. Kazura, M.M. Fanning, J.L. Blumer, A.A.F. Mahmoud, J. Clin. Investig. 67, 93-102 (1981)

151. P. Geddes, Proc. R. Soc. B Biol. Sci. 30, 200-205 (1880)

152. C. Fleury, F. Marin, B. Marie, G. Luquet, J. Thomas, C. Josse, A. Serpentini, J.M. Lebel, Tissue Cell 40, 207-218 (2008)

153. M.B. Johnstone, N.V. Gohad, E.P. Falwell, D.C. Hansen, K.M. Hansen, A.S. Mount, J. Exp. Mar. Biol. Ecol. 463, 8-16 (2015)

154. A. Abolins-Krogis, Cell Tissue Res. 172, 455-476 (1976)

155. M.P. Cajaraville, S.G. Pal, Cell Struct. Funct. 20, 355-367 (1995)

156. P.M. Hermann, J.J. Nicol, G.T. Nagle, A.G.M. Bulloch, W.C. Wildering, J. Comp. Neurol. 492, 383-400 (2005)

157. A. Hamza-Chaffai, R. Ladhar-Chaabouni, Cytotechnology 68, 1789-1805 (2016)

158. M. Gimona, M. Herzog, J. Vandekerckhove, J.V. Small, FEBS 274, 159-162 (1990)

159. F.A.N. Weimin, H.U. Yilin, L.I. Changzhong, Tsinghua. Sci. Technol. 13, 466-473 (2008)

160. L.E. Wagge, Int. Rev. Cytol. 4, 31-78 (1955)

161. T. Sminia, in Invertebrate Blood Cells, edited by N. A. Ratcliffe, A. Rowley (Academic Press, London-New York, 1981), pp. 191-232.

162. K.J. Lie, D. Heyneman, P. Yau, J. Parasitol. 61, 574-576 (1975)

163. K.H. Jeong, L.K. Joe, D. Heyneman, Dev. Comp. Immunol. 7, 217-228 (1983)

164. S.S. Sdos, Z.A. Andrade, Mem. Inst. Oswaldo Cruz 101, $213-$ 218 (2006)

165. M. Jemaa, N. Morin, P. Cavelier, J. Cau, J.M. Strub, C. Delsert, J. Exp. Biol. 217, 3067-3077 (2014)

166. L. Addadi, S. Weiner, Phys. Scr. 89, 098003 (2014)

167. L. Addadi, D. Joester, F. Nudelman, S. Weiner, Chem. A Eur. J. 12, 980-987 (2006)

168. A. Miglioli, R. Dumollard, T. Balbi, L. Besnardeau, L. Canesi, U. Genova, C. Europa, Proc. R. Soc. B 286, 20192043 (2019)

169. H. Ehrlich, Marine Biological Materials of Invertebrate Origin (Springer International Publishing, Cham, 2019), pp. 1-329

170. S. Matsumura, S. Kajiyama, T. Nishimura, T. Kato, Small 38, 5127-5133 (2015)

171. H. Ehrlich, M. Motylenko, P.V. Sundareshwar, A. Ereskovsky, I. Zgłobicka, T. Noga, T. Płociński, M.V. Tsurkan, E. Wyroba, S. Suski, H. Bilski, M. Wysokowski, H. Stöcker, A. Makarova, D. Vyalikh, J. Walter, S.L. Molodtsov, V.V. Bazhenov, I. Petrenko, E. Langer, A. Richter, E. Niederschlag, M. Pisarek, A. Springer, M. Gelinsky, D. Rafaja, A. Witkowski, D.C. Meyer, T.
Jesionowski, K.J. Kurzydłowski, Adv. Funct. Mater. 26, 2503 $2510(2016)$

172. H. Ehrlich, Int. Geol. Rev. 52, 661-699 (2010)

173. H.C.W. Skinner, H. Ehrlich, Biomineralization (Elsevier, New York, 2013), pp. 105-162

174. M. Wysokowski, T. Jesionowski, H. Ehrlich, Am. Mineral. 103, 665-691 (2018)

175. R. Zhang, L. Xie, Z. Yan, Biomineralization Mechanism of the Pearl Oyster, Pinctada Fucata (Springer, Berlin, 2018), pp. $1-737$

176. W. Jin, S. Jiang, H. Pan, Crystals 8, 48 (2018)

177. J. Seto, Advanced Topics in Biomineralization (InTech, Rijeka, 2012), pp. 6-174

178. F. Marin, N. Le Roy, B. Marie, Front. Biosci. 4, 1099-1125 (2012)

179. M.S. Fernández, F. Valenzuela, J.I. Arias, J.L. Arias, J. Struct. Biol. J. 196, 187-196 (2016)

180. D. Tsurkan, M. Wysokowski, I. Petrenko, A. Voronkina, Y. Khrunyk, A. Fursov, Appl. Phys. A 126, 382 (2020)

181. A. Bobbio, Bull. Hist. Dent. 20, 1-6 (1972)

182. A. De Waele, Bull. l'Académie R Des Sci. Belgique Cl. Des Sci. 10, 1-52 (1930)

183. S.P. Kapur, A.S. Gupta, Biol. Bull. 139, 502-509 (1970)

184. C. Hatchett, Philos. Trans. R. Soc. Lond. 89, 315-334 (1799)

185. M. Frémy, Ann. de Chimie et de Physique 43, 47-107 (1855)

186. O.B. B $\emptyset$ ggild, The Shell Structure of the Mollusks (A.F. Host Kjobenhavn, Copenhagen, 1930), pp. 231-325

187. T. Furuhashi, C. Schwarzinger, I. Miksik, M. Smrz, A. Beran, Comp. Biochem. Physiol. Part B 154, 351-371 (2009)

188. S. Auzoux-Bordenave, M. Fouchereau-Peron, M.-N. Helleouet, D. Doumenc, J. Shellfish Res. 26, 887-894 (2007)

189. R.P. Henry, D.G. Saintsing, Physiol. Zool. 56, 274-280 (1983)

190. A. P. Wheeler, in Calcification in Biological Systems, edited by E. Bonucci (CRC Press, London, 1992), pp. 179-210.

191. M. Lopes-Lima, I. Ribeiro, R.A. Pinto, J. Machado, Comp. Biochem. Physiol. Part A 141, 319-326 (2005)

192. K. Wilbur, in Physiology Mollusca, edited by K.M. Wilbur, C.M. Yonge, I (Academic Press, New York, 1972), pp. 243-282.

193. A.S.M. Saleuddin, W. Chan, Can. J. Zool. 47, 1107-1111 (1969)

194. W.C. Durning, J. Bone Jt. Surg. 39, 377-393 (1957)

195. A.S.M. Saleuddin, K.M. Wilbur, Can. J. Zool. 47, 51-53 (1969)

196. A.S.M. Saleuddin, M.B. Fenton, Can. J. Zool. 84, 410-424 (1970)

197. G. Falini, S. Al, S. Weiner, L. Addadi, Science 271, 67-69 (1996)

198. J. Xie, J. Liang, J. Sun, J. Gao, S. Zhang, Y. Liu, L. Xie, R. Zhang, Cryst. Growth Des. 16, 672-680 (2016)

199. Y. Politi, J. Mahamid, H. Goldberg, S. Weinera, L. Addadi, CrystEngComm 9, 1171-1177 (2007)

200. P.L. Blackwelder, N. Watabe, Biomineralization 9, 1-10 (1977)

201. A.S.M. Saleuddin, J. Molluscan Stud. 37, 371-380 (1967)

202. A. Chróścicka, Z. Jaegermann, P. Wychowański, A. Ratajska, J. Sadło, G. Hoser, S. Michałowski, M. Lewandowska-Szumiel, Ann. Biomed. Eng. 44, 2145-2157 (2016)

203. B. Kruppke, J. Farack, S. Weil, E.D. Aflalo, D. Polakova, A. Sagi, T. Hanke, J. Biomed. Mater. Res. 108, 694-708 (2019)

204. S. Biradar, P. Ravichandran, R. Gopikrishnan, V. Goornavar, J.C. Hall, V. Ramesh, S. Baluchamy, R.B. Jeffers, G.T. Ramesh, J. Nanosci. Nanotechnol. 11, 6868-6874 (2011)

205. Y. Fujita, T. Yamamuro, T. Nakamura, S. Kotani, C. Ohtsuki, T. Kokubo, J. Biomed. Mater. Res. 25, 991-1003 (1991)

206. H. Bahrom, A.A. Goncharenko, L. Fatkhutdinova, O. Peltek, A. Muslimov, O. Koval, I.E. Eliseev, A. Manchev, D. Gorin, I.I. Shishkin, R.E. Noskov, A.S. Timin, P. Ginzburg, M.V. Zyuzin, A.C.S. Sustain, Chem. Eng. 7, 19142-19156 (2019) 
207. D. Geblinger, B. Geiger, L. Addadi, ChemBioChem 10, 158-165 (2008)

208. E. Tolba, W.E.G. Müller, B.M.A. El-Hady, M. Neufurth, F. Wurm, S. Wang, H.C. Schröder, X. Wang, J. Mater. Chem. B 4, 376-386 (2016)

209. A.D. Woldetsadik, S.K. Sharma, S. Khapli, R. Jagannathan, M. Magzoub, A.C.S. Biomater, Sci. Eng. 3, 2457-2469 (2017)

210. Y. Liu, Y. Zhou, T. Jiang, Y. De Liang, Z. Zhang, Y.N. Wang, Int. J. Oral Sci. 9, 133-138 (2017)

211. X. Wang, H.C. Schröder, W.E.G. Müller, Trends Biotechnol. 32, 441-447 (2014)

212. V. Tollemar, Z.J. Collier, M.K. Mohammed, M.J. Lee, G.A. Ameer, R.R. Reid, Genes Dis. 3, 56-71 (2016)

213. P.D. Costantino, D. Hiltzik, S. Govindaraj, J. Moche, Facial Plast. Surg. 18, 13-26 (2002)

214. U.M.E. Wikesjö, W.H. Lim, S.S. Razi, T.J. Sigurdsson, M.B. Lee, D.N. Tatakis, W.R. Hardwick, J. Periodontol. 74, 957-964 (2003)

215. G. Polimeni, K.-T. Koo, M. Qahash, A. Xiropaidis, J. Albandar, U.M.E. Wikesjo, J. Clin. Periodontol. 31, 725-729 (2004)

216. A.S. Mount, N.V. Gohad, D.C. Hansen, K. Muller, M.B. Johnstone, US 8,541,031 B2 (2013).
217. V.R. Meenakshi, G. Donnay, P.L. Blackwelder, K.M. Wilbur, Calcif. Tissue Res. 15, 31-44 (1974)

218. C. Klinger, S. Żółtowska-Aksamitowska, M. Wysokowski, M.V. Tsurkan, R. Galli, I. Petrenko, T. Machałowski, A. Ereskovsky, R. Martinović, L. Muzychka, O.B. Smolii, N. Bechmann, V. Ivanenko, P.J. Schupp, T. Jesionowski, M. Giovine, Y. Joseph, S.R. Bornstein, A. Voronkina, H. Ehrlich, Mar. Drugs 17, 131 (2019)

219. I. Petrenko, A.P. Summers, P. Simon, S. ŻółtowskaAksamitowska, M. Motylenko, C. Schimpf, D. Rafaja, F. Roth, K. Kummer, E. Brendler, O.S. Pokrovsky, R. Galli, M. Wysokowski, H. Meissner, E. Niederschlag, Y. Joseph, S. Molodtsov, A. Ereskovsky, V. Sivkov, S. Nekipelov, O. Petrova, O. Volkova, M. Bertau, M. Kraft, A. Rogalev, M. Kopani, T. Jesionowski, H. Ehrlich, Sci. Adv. 5, 2805 (2019)

Publisher's Note Springer Nature remains neutral with regard to jurisdictional claims in published maps and institutional affiliations. 